\title{
Income Attainment During Transformation Processes A Meta-Analysis of the Market
Transition Theory
}

\author{
Willem-Jan Verhoeven, Wim Jansen and Jos Dessens
}

The changing communist regime in China and the 'velvet' revolutions in Central and Eastern Europe (CEE) have provided an opportunity to investigate trends in income attainment during processes of transformation. Nee (1989) formulated the market transition theory, which indicates the main determinants of changing income attainment during the transformation process from a state-regulated, centrally planned economy to a market economy. An extensive literature, with studies testing the predictions derived from this theory on China and CEE, has emerged since this seminal article by Nee. However, there are theoretical and empirical inconsistencies in these studies. This calls for a systematic comparison of the empirical results and evaluation of Nee's theory. This paper reports a meta-analysis performed on 64 publications to determine to what extent there is consistent empirical evidence for the hypothesized relationship between marketization processes and the changing effect of income determinants. We found that political capital remains important during transformation in urban China, the gender gap in income increases in urban China as well as in CEE, and although human capital and market-related resources are important determinants of income, it is not evident that their importance increases during the transformation process. We find some support in favor of the market transition theory, but it needs revision and elaboration.

The worldwide decline of state socialism and its implications for social inequality has attracted the attention of many authors. The first transition to market economy conditions emerged in rural China around 1978, when the People's Communes of Mao were disbanded and collective economies were replaced by a household responsibility system (Bian, 2002; Walder, 2002). Households became the main unit of production, distribution, and consumption. Despite the general idea of gradual reform, this early transformation was radical and abrupt. Land was divided equally among households, and a number of restrictions on production and population movements were abandoned. Households were allowed to produce commodities and individuals were allowed to leave home to make a better future outside the boundaries of their collectives. A decade later, the economic, political, and social changes in the former communist and socialist countries of Europe and the Soviet Union were even more dramatic. In the words of Stark (Stark, 1992a: 299), 'Communism and State Socialism are being exchanged for a vision packaged with formulas for applying economic science to the grand project of institutional reconstruction; it 
promises prosperity through sacrifice.' Up to the end of the 1980s, the Soviet Union had enforced the communist ideology in its satellite states, with regular massive protests as a witness of this involuntary enforcement. From 1989, peaceful popular uprisings ended the communist era of the Soviet Empire. A few years later, the federal states were even more fragmented: the Soviet Union and Yugoslavia in 1991 and Czechoslovakia in 1992.

The emerging market economies in China and CEE provide a unique opportunity to study the introduction and expansion of market mechanisms and their influence on stratification in a quasi-experimental manner. Many researchers have been inspired by this sociological problem, which can be expressed by the question: Who are the winners and losers of the transformation process (Ganzeboom, 1998; Hauser and Xie, 2001)? This contribution focuses on one specific aspect of stratification research: the distribution of income.

A large part of the literature on societies in transition consists of studies exploring trends in income and income inequality. Many studies address the question of whether income inequality increases or decreases during transformation processes. For CEE, the consensus at this point is that income inequality increased significantly over the approximately three-year period after 1989. After this period, inequality gradually declined (Atkinson and Micklewright, 1992; Dessens et al., 1998; Flemming and Micklewright, 1999). In rural China, income inequality decreased over the first several years of reforms and has subsequently increased (Griffin and Renwei, 1993; Khan et al., 1992). Urban China has also shown an increase in income inequality since the first several years of reform (Xu and Zou, 2000).

An increase in income inequality implies that some people get more income, some people get less, or both. ${ }^{1}$ Another branch of stratification research in transitional countries investigates which social groups have an income advantage during the transformation process. A prominent theory addressing this question is the market transition theory (MTT) (Nee, 1989, 1991, 1996), which proposes bold and innovative predictions ('theses') linking the process of marketization to such stratification outcomes as income attainment and income inequality. While Nee originally proposed the theory for China, it is considered to be a general theory for societies in transition, and its predictions should be applicable to all countries undergoing transitional processes. It claims that the introduction and expansion of market institutions give rise to multiple bases of power and privilege and change the structures of opportunity and incentive. The former political elite no longer have absolute control over resources of power and privilege. Labor markets are rearranged and there are changes in the structure of property rights, resulting in a decline in political power in the competition over resources, with power becoming market-based. Human capital provides more income benefits, while the influence of political capital wanes.

In terms of winners and losers, the theory claims that members of the former political elite are among the losers in the transformation process. They have to give ground to the direct producers of economic goods, as well as to the new elite, which consists of highly educated professionals, managers, and entrepreneurs, who can be seen as winners. Furthermore, the theory not only claims that the changing structure of property rights increases opportunities for entrepreneurs, but it also increases opportunities for those employed in the private/hybrid sector as well. Increasing opportunities and returns to human capital should also endorse equal pay between men and women (Nee and Matthews, 1996).

The MTT has been tested in numerous different studies of China as well as CEE, and theoretical and empirical inconsistencies are prevalent (Fligstein, 1996; Nee, 1996; Oberschall, 1996; Parish and Michelson, 1996; Stark, 1996; Szelényi and Kostello, 1996; Walder, 1996; Xie and Hannum, 1996). Two main aspects of the theory have been criticized. First, the hypothesis that the political elite lose their income advantage has been questioned. Róna-Tas (1994) claims that former and current party members are able to convert their political capital to economic advantage. Second, the assumption that all transitional economies converge towards Western capitalism has been criticized. In the words of Stark (1996: 994), 'Within the transformation problematic, the present is studied as an approximation of a designated future (Blanchard etal., 1994), risking an underlying teleology in which concepts are driven by hypostatized end-states.'

Some authors believe that synthesizing theoretical perspectives can provide a solution for these controversial outcomes (Szelényi and Kostello, 1996; Zhou, 2000); however, Cao and Nee (2002: 3 ) argue that rushing to a synthesis could lead to artificial compromise and uncritical acceptance. They believe that further elaboration of existing theoretical perspectives and more informed empirical observations are crucial. Either way, it becomes clear that the market transition debate has reached the point where MTT claims should be subjected 
to a thorough evaluation. How far have we come in understanding and predicting the influence of dramatically changing economic institutions on income attainment? Nee and Cao have published summaries of empirical studies relevant to the MTT (Cao and Nee, 2000, Table 1; Nee and Cao, 1999, Table 1; Nee and Cao, 2002, Table 1). While their summaries are not complete for the period up to 2002 and their interpretations of the study results are qualitative, they conclude that the predictions derived from the MTT are empirically supported. The method used by Nee and Cao to summarize these studies is comparable to the vote-counting method (Hunter et al., 1982; Light and Smith, 1971). The major disadvantage of this method is its vulnerability to flawed and misleading conclusions. ${ }^{2}$

In the present study, we extend the Nee and Cao reviews and introduce a more systematic and quantitative meta-analytic approach aimed at performing a fullfledged research synthesis, following the three points provided by Hall etal. (1994): determining cause and effect, theory development, and generalization. First, we want to determine whether there is consistent empirical evidence for the changing effects of the determinants of income that have been hypothesized. Second, the process of testing hypotheses in a meta-analytic research design should provide information on aspects of the theory that need revision or elaboration. Third, the MTT may be enriched by searching for variations in the influence of markets on income attainment in different regions.

\section{The Market Transition Theory}

As pointed out in the introduction, the MTT aims to describe how processes of marketization influence stratification outcomes like income and income inequality. The theory consists of three interrelated theses - the 'market power thesis,' the 'market incentive thesis,' and the 'market opportunity thesis' - from which four general predictions are deduced.

The market power thesis ${ }^{3}$ claims that the more market mechanisms are introduced, the more likely it is that control over resources is located less in the redistributive economy and more in market-like exchanges. Furthermore, the change in the macro-economic supply-anddemand structure towards more marketization will decrease the intervention of administrative fiat, and the prices of labor and goods will be agreed upon more by buyer and seller. These two aspects of marketization should transfer power over economic resources to the direct producers at the expense of the redistributers.
According to Nee (1989: 671), this implies that 'not only are the direct controllers of the redistributive mechanisms likely to experience a relative loss, but the value of their political capital accumulated through prior experience as cadre is likely to diminish as well'. Under state socialism, party membership operates as a source of material well-being (Gerber, 2000). The positions through which privileges were accumulated under state socialism will perish as more control over resources is located in market-like exchanges. We can derive a prediction from the market-power thesis that earnings should decrease accordingly:

Returns to political capital in terms of earnings (income) decrease during the transformation process.

The market-incentive thesis claims that in redistributive economies, market-determined prices for labor are more sensitive to differential performance than labor prices that are set administratively. Market economies tend to be more efficient because prices are mutually agreed upon by buyer and seller, and 'as a result, a greater share of the surplus is retained by direct producers (Nee, 1989: 666)'. Marketization not only benefits direct producers, but the close relationship between economic rewards and individual productivity stimulates individual efforts and investments as well. Because the characteristics of human capital are interpreted as indicators of individual productivity, this incentive mechanism should be reflected in higher returns to human capital. The following prediction can be derived from the market incentive thesis:

Returns to human capital in terms of earnings (income) increase during the transformation process.

The market opportunity thesis claims that the transformation from a redistributive economy generates more opportunities for income attainment. We can derive two predictions from this. There is a hypothesized effect of entrepreneurship on income and an effect of working in the private/hybrid sector on income. Increasing opportunities make room for new occupational categories like entrepreneurship and self-employment. The transformation towards marketization changes property relations and generates a new economic elite, of which entrepreneurs are a part. Therefore, we can derive the following prediction:

Entrepreneurship increases earnings (income) during the transformation process.

Increasing opportunities also generate expansion in the private/hybrid sector, which results in more opportunities to work in private or hybrid firms (private sector) instead of state-owned firms (state sector). People 
working in the private sector are more likely to be rewarded according to their productivity and, subsequently, earn higher incomes than people working in the state sector. Firms in the private sector will be less reluctant to reward their employees' personal efforts than will firms in the state sector, leading to the following prediction:

Returns, in terms of earnings (income), to employment in the private/hybrid sector of the economy relative to employment in the state sector increase during the transformation process.

We can also draw inferences about the effect of marketization on gender income inequality. Under the condition that markets reward individual productivity, women should have more incentives to invest in their own human capital, ultimately leading to higher average earnings. Nee and Matthews (1996: 428-29) argue that 'the gender wage gap narrows, the more extensive the shift to markets and the higher the rate of economic growth'. However, this holds only under specific conditions. Rural woman are able to improve their position and their contribution to household income when the region sustained marketdriven economic development, but they have a hard time to keep up with the rapidly industrializing economy (Matthews and Nee, 2000). Others claim that women gain in comparison to men, because they work mainly in sectors that are less adversely affected by the transformation process (Fodor, 1997; Orazem and Vodopivec, 1995). Therefore, it can be predicted that changes in returns to human capital and differential reward systems between sectors will decrease the overall gender pay gap:

The difference in earnings (income) between men and women decreases during the transformation process.

\section{Meta-Analysis}

Meta-analysis can be described as the analysis of the analyses, because the data used in the meta-analysis are from studies already performed. The term meta-analysis encompasses all quantitative research methods and techniques of summarizing the results of empirical studies. By the end of the 1970s, three different studies appeared almost simultaneously, in which methods using similar statistical approaches for synthesizing research were developed (Rosenthal and Rubin, 1978; Schmidt and Hunter, 1977; Smith and Glass, 1977). Since then, meta-analysis has been widely accepted in disciplines like psychology, the health sciences, and educational research. Despite the abundance of empirical findings, we do not know of any meta-analyses performed in stratification research.
The results from the empirical studies to be summarized are expressed into effect sizes that will be 'meta'-analyzed. In most meta-analyses, the effect size is the difference between the mean scores of experimental and control groups. Odds ratios and Pearson's product-moment correlation coefficients are also used as effect sizes (Lipsey and Wilson, 2001). In the present study, the effect sizes are the regression coefficients of determinants of income. In the section on data, variables, and coding, the problems related to the use of regression coefficients as effect sizes will be discussed in greater detail, along with possible solutions.

A common summary statistic in meta-analysis is the weighted mean effect size: each effect size is weighted by the inverse of its variance $\left(1 / S E^{2}\right) .{ }^{4}$ According to Shadish and Haddock (1994: 265), 'the variance is inversely proportional to within-study sample size, meaning: the larger the sample, the smaller the variance, so the more precise the estimate of effect size should be'. ${ }^{5}$ The mean effect size $E S$, weighted by the inverse of the variances is calculated for $n$ independent effect sizes $E S_{i}$ as follows:

$$
\overline{E S}=\frac{\sum_{i=1}^{n} w_{i} \times E S_{i}}{\sum_{i=1}^{n} w_{i}} \text { with } w_{i}=1 / S E_{i}^{2}
$$

Whether the weighted mean effect size significantly deviates from zero can be determined by calculating the SEs of the weighted mean effect size. ${ }^{6}$ More interestingly, however, the analysis of heterogeneous distributions of weighted effect sizes may reveal that the variability across weighted effect sizes is greater than expected from sampling error alone; rejecting homogeneity. How we deal with this access variability in effect sizes will be discussed in the analysis section.

Every meta-analytic research design should follow at least five stages: problem definition; sample definition; data, variables and coding discussion; data analysis; and presentation of results (Cooper, 1982). The definition of the problem was set out in the first section of this paper; the remaining stages are discussed in the following sections.

\section{Sample Definition}

Most of the literature on meta-analysis stresses the importance of conducting an extensive, well-documented literature search, resulting in a sample of studies (Glass etal., 1981; Hunter and Schmidt, 1990; Hunter et al., 
1982; Lipsey and Wilson, 2001). However, it is never possible to state that the list of studies is exhaustive, so it is difficult to determine whether the publications used form a representative sample. Before starting the search, it is important to compile a list of carefully selected criteria that define the population of studies that should be included. The list should be structured by study characteristics that can serve as variables explaining the differences in outcomes between studies (Snijders, 1997: 3-5). Our population is defined by studies (a) performed in China and CEE, (b) estimating effects on income, and (c) including at least one of the determinants suggested by the MTT. We tried to include as many publications as possible, focusing not only on journal articles, books, and chapters of edited books, but also on dissertations, reports, and conference papers.

We used the following sources in selecting publications for our sample: references in publications, computerized bibliographic databases (Jstor and Ebsco), relevant journals, ${ }^{7}$ conference programs and proceedings, review articles, internet sources, ${ }^{8}$ and authors or experts in the research field of interest.

\section{Data, Variables and Coding}

\section{Data}

In total, we obtained a sample of 90 relevant publications. Studies that tested the MTT predictions directly were not included in the analysis. These were studies that used the difference between income before and during the transformation process as the dependent variable or used income during the transformation process as the dependent variable and income before as a covariate (Domanski and Heyns, 1995; Fabig, 1999; Gerber and Hout, 1998; Kropp, 1998; Mateju and Reháková, 1996; Nee, 1989; Nee and Liedka, 1997; Ogloblin, 1999; Orazem and Vodopivec, 2000; Róna-Tas, 1994). We excluded these studies from our analyses because they are not comparable with studies using the logarithm of income as the dependent variable. It was also not possible to analyze them separately in a meta-analytic research design because there were too few.

The effect sizes retrieved from our sample of studies in the meta-analysis presented us with several comparability issues. The dependent variables are defined differently - for example, as hourly or monthly earnings, household income, or earnings - and the effects of the determinants of income can expected to be different for different definitions. Earnings are determined by personal characteristics and household income also by household composition. Furthermore, comparing income across countries and periods introduces different currencies and inflation rates. As a result, the effects of the determinants of income are measured on different scales. Selecting studies that use $\ln$ (income) as the dependent variable will solve this problem because then all effects are represented as a relative increase or decrease of the dependent variable. ${ }^{9}$

We performed additional analyses to check the extent to which our results would be affected by taking total income or salary as the dependent variable. Although we found differences, the conclusions remained the same.

Besides the comparability issues concerning the dependent variables used in the original studies, there is considerable variation in the data, designs, model specifications, and operationalizations of the different studies. As a result, it was difficult to aggregate the effect sizes in a straightforward manner. Some of the variables were recoded and new variables were constructed to control for differences between studies. Dummy variables were used to assess the completeness of and differences between the analytical models used in the original studies. These solutions are described more extensively in the section on variables and coding, below. Although metaanalyses are criticized for summarizing empirical results that are not conceptually comparable, to some extent, we were able to deal with these comparability issues; however, we acknowledge that not all of the solutions for the comparability issues proposed in this metaanalysis are sufficient.

Prior research has shown that the countryside and the Cities represent two different social worlds (Nee, 1996; Parish and Michelson, 1996; Peng, 1992). Systematic differences between urban and rural China exist before 1978 and during the transformation process. Our analytical models should reflect this rural/urban distinction. Unfortunately, it was decided to exclude the studies on rural China. ${ }^{10}$ From here on we speak of China if we refer to urban China.

Finally, some studies did not report the necessary statistical information - like SEs, t-values, or $P$-values needed for a quantitative meta-analysis. These were also excluded, leaving a final 64 studies to be analyzed. ${ }^{11}$

\section{Variables and Coding}

For the effect sizes, we used the regression coefficients of six determinants of income. In the analysis of the 'power' prediction, the coefficients of the variable cadre or party membership ${ }^{12}$ have been used as the effect sizes. Descriptive statistics of all variables are reported in Table 1. 


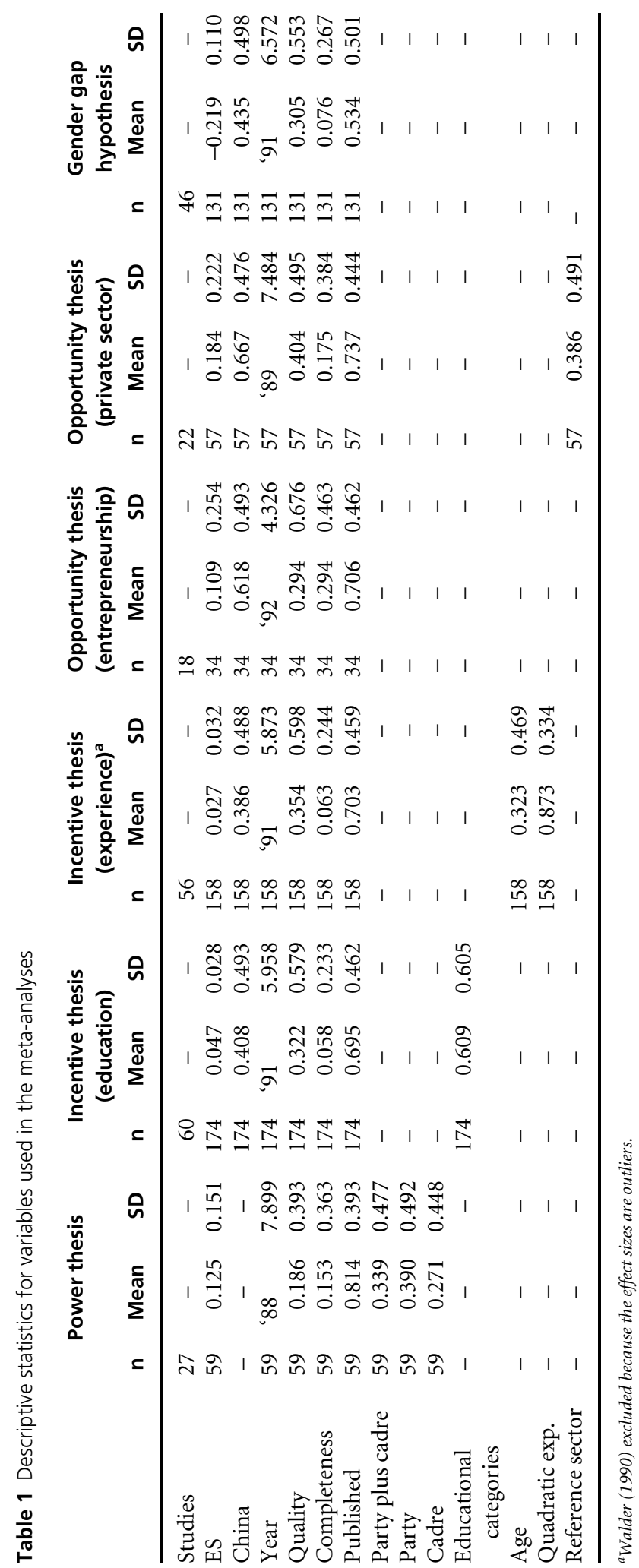


Because we have only eight observations for CEE countries we will restrict the test of the power prediction to China, leaving a total of 27 available studies. Some of these studies are comparative meaning that from some studies multiple effect sizes are available, leading to 59 independent effect sizes, as is shown in Table 1.

Testing the theoretical ideas on the supposed changing income advantages of party members is not straightforward. People could attain income advantages for just being a member of the communist party; based on 'loyalty'. On the other hand there was a relatively small group of party members who occupied 'real' privileged positions; (high-rank) cadres or administrators. Because we are interested in the changing returns to political capital, we used the regression coefficients of party membership where available. In other cases, we had to settle for the regression coefficients of cadre or administrator. In doing so, we run the risk of wrongly concluding that the relative income advantages of party membership do not decrease or even increase during transformation processes. Some authors believe that high rank cadre members were able to adapt to the market changes. Their income advantages do not stem directly from the fact that they are members of the communist party but from characteristics that got them into the privileged position in the first place or capabilities they accumulated through their position.

Some studies have tried to disentangle this problem and investigated the effects of both variables on income. In our analysis we will use three dummy variables to see to what extent these different concepts influence our results: party plus cadre (' 1 ' if party plus cadre and ' 0 ' if else), cadre (' 1 ' if cadre and ' 0 ' if else), and party (' 1 ' if party and ' 0 ' if else).

In MTT education is used as a representation of human capital, arguing that returns to education are among the best indicators of human productivity (Mincer, 1958; Schultz, 1963). However, 'human capital' includes inherent characteristics from which people cannot be separated, such as knowledge, skills, health, and values (Becker, 1993). We extended the test of the 'incentive' prediction by analyzing not only the regression coefficients of the variable years of education but the coefficients of years of experience as well. These effects were analyzed separately, and it should be noted that not all studies use years of education to determine the effect of education on income. Table 1 shows that we have 174 independent 'education' effect sizes retrieved from 60 studies and 158 independent 'experience' effect sizes retrieved from 56 studies for testing the incentive prediction. ${ }^{13}$ In our sample, 60 percent of the published research on educational effects used educational categories. In these analyses, a dummy variable was incorporated into the analytical model for each educational level defined, which left us with several coefficients representing the effect of education on income. In order to summarize the results of the relationship between education and income, the coefficients of the educational categories were transformed into one coefficient representing the effect of years of education on income. Using information on the educational systems of the countries under investigation, the various educational levels were transformed into the years of education required to attain a specific educational level. To give an example, the coefficient of a university degree for China equals 11 years when elementary school or less is the reference category. An estimation procedure was used to predict the 'educational year' coefficient based on the coefficients for the various educational levels and the number of years corresponding to each of these levels, assuming a fixed correlation $(0.35)^{14}$ between the educational dummy variables in the original studies. Analyzing the transformed years of education as effect sizes is less reliable than analyzing the actual years of education. For determining the extent to which this would influence our analysis, we included a dummy variable transformation (' 1 ' if transformed years of education and ' 0 ' if years of education were reported).

The relationship between experience and income is also operationalized differently in the original studies. In about two-thirds of the studies investigating the relationship between experience and income, actual years of experience were measured. All other studies used age of the respondent as a proxy for experience. In order to adjust the coefficients of age to resemble the effects of experience, information is needed on the age when each respondent left school. ${ }^{15}$ Another way to adjust the coefficient of age is to use information on age at first occupation or current occupation. Since we did not have this information, we incorporated a dummy variable age (' 1 ' if age and ' 0 ' if years of experience) to control for differences between studies using age and those using actual experience. Finally, most studies have used quadratic modeling of experience, but some have analyzed experience linearly. We have incorporated an additional dummy variable quadratic exp. (' 1 ' if the squared version of experience is included in the model and ' 0 ' if the linear version is used) to determine the extent to which our analysis could be influenced by these differences in modeling.

For the analysis of the 'entrepreneurship' prediction, the coefficients of the variable entrepreneurs (self-employed) 
were used (34 independent effect sizes retrieved from 18 studies); for the 'private sector' prediction, the coefficients of the variable private (non-state) sector were used (57 independent effect sizes retrieved from 22 studies). The effect of employment in the private sector on income is not always compared to employment in the public or state sector (using a dummy variable in the original analyses). Sometimes the effects on income of an array of industrial sectors have been compared. We have used a dummy variable reference sector to measure the extent to which this difference affects our analysis (' 1 ' if employment in the public or state sector is the reference category and ' 0 ' if some other sector is the reference category).

Finally, the gender dummy was used to test the 'gender gap' hypothesis. We have 131 independent effect sizes retrieved from 46 studies. We recoded some of the coefficients so that all effect sizes represent coefficients of a dummy variable female (' 0 ' if male and ' 1 ' if female).

We had to compute additional variables for testing our hypotheses and for more general solutions to control for differences between studies. The actual test of the hypotheses involved determining whether the effect sizes during the transformation process were significantly different from those before, and whether these differences change during the transformations process. In the introduction, we mentioned that 1978 is generally assumed to be the year the market reforms started in China. For most CEE countries, the transition year is assumed to be around 1989 or 1990 (Hanley and Treiman, 2001), and 1991 for Russia. Because transformation reforms do not take effect immediately, we have compared the period before 1980 with the period after for the Chinese situation and the period before and after 1991 for CEE. While these transition years may seem arbitrary, descriptive analyses have shown that the obvious changes in measures of income inequality occur a few years after transformation is assumed to have started (Dessens etal., 1998; Flemming and Micklewright, 1999). Effect sizes are available for the period 1960 to $2001,{ }^{16}$ which is represented by the variable year ${ }^{17}$ (in most cases, this corresponds to the survey year, while others are based on retrospective reporting).

MTT implies that there are different market outcomes but it appears to assume convergence of consequences (Parish and Michelson, 1996). The introduction and expansion of market mechanisms should result in decreasing returns to political capital, increasing returns to human capital, higher wages for entrepreneurs and employment in the private sector, and a decreasing gender gap in any given transition country. Determining whether variations in effect sizes can be attributed to differences between regions can test this idea. Unfortunately, the small number of cases did not allow us to analyze the CEE countries separately, so they have been analyzed as one region. The dummy variable China (' 1 ' if China and ' $O$ ' if CEE) was used to capture the differences between China and CEE.

Difficulties concerning variations in design and model specifications have been dealt with in two ways. First, we used the variable, quality, which is often introduced to capture the variation between studies (Shadish and Haddock, 1994). We scored the study quality based on three criteria: (a) design, (b) method used, and (c) the way the researchers took the phase of the transformation process into account. Based on these scores, we categorized the studies as 'poor', 'medium', and 'good'. Studies based on longitudinal data using covariates to capture the transformation process were categorized as having good quality. Studies based on longitudinal data without covariates to capture the transformation phase or based on cross-sectional data using covariates to capture the transformation phase were categorized as having medium quality. ${ }^{18}$ Studies based on cross-sectional data without analytical improvements were categorized as having poor quality. It is difficult to claim whether studies with good quality generate higher or lower effect sizes than studies with poor quality. However, this is not at issue here. The most important justification for using quality as an indicator for differences between studies is to check to what extent differences in design, method, and conceptualization of the transformation process generates differences at all.

Second, not all models use the same set of variables, which can influence the effects of the determinants of income. For example, compare a fictional regression model of income on gender and one of income on gender and years of education. The coefficient of the gender variable in the first model should be interpreted as the income difference between men and women. The interpretation of the gender coefficient in the second model should be interpreted as the income difference between men and women with the same years of education, which would most likely be smaller than the difference in the first model. To give some insight into the extent to which this influenced our analyses, we include the variable completeness. The completeness of the models was determined based on the variables related to the determinants of income discussed in the MTT (party membership, education and experience (human capital), entrepreneurship, employment in the private sector, and 
gender). If all of these variables were incorporated in the model of the original study, the study was coded ' 1 ', all studies lacking at least one MTT variable were coded ' 0 '.

Using a variable conceptualizing the completeness of the models used in the original studies can be justified in two ways. First, it can be expected that coefficients of determinants of income estimated in elaborated models will be a better approximation of net effects than coefficients estimated in less elaborated models. Second, because MTT emphasizes relative losses and gains, studies that analyzed elaborate models will test the MTT predictions more accurately than studies using less elaborated models.

Finally, there is a tendency to publish significant positive results (White, 1994). Since we retrieved studies from published sources as well as unpublished dissertations, reports, and conference papers, we used a dummy variable published (' 1 ' if published and ' 0 ' if gray literature) to see whether this would influence our results.

\section{Data Analysis}

According to Lipsey and Wilson (2001), the meta-analyst can take three different approaches when the variability across effect sizes exceeds sampling error. First, the excess variability can be assumed to result from random differences between studies (random effects model). Second, the excess variability can be assumed to result from completely systematic study differences (fixed effects model). Third, it may be assumed that the excess variability partly results from random study differences and partly from systematic differences (mixed effects model).

We expect that the excess variability is partly associated with some independent variables. First of all, we are interested in whether the effects of determinants of income change during processes of transformation. So, we assume that the effect sizes are a function of time. Second, we have constructed variables that take into account differences between studies: design, coding, and models. The data we use have limited information with respect to operationalization of systematic differences between studies. It is not possible to model differences between definitions of income, all differences between models used in the original studies, or differences between all the CEE countries. Hence, we cannot be certain that the moderator effects we can use, account for all the excess variability across effect sizes and therefore assume that part of the excess variability is random and cannot be modeled. The mixed effects model is an appropriate model in this situation because it allows part of the excess variability to be modeled using known moderators and part to be modeled randomly.

The first analysis of the power prediction, which is restricted to China, assumes that the effect sizes are a function of time. This leads to a 'standard' meta-regression analysis, ${ }^{19}$ where the effect sizes are the dependent variable $\left(E S_{\text {pow }}\right)$, and a variable indicating the year of income determination would be the independent variable.

$$
E S_{\text {pow }}=\beta_{0}+\beta_{1} \text { Year }
$$

The constant, $\beta_{0}$, of this meta-regression model represents the weighted mean effect size in 1980, because for this analysis we centered year around 1980. The coefficient $\beta_{1}$ indicates the increase or decrease of the weighted mean effect size by one year.

In the case of the analyses of the other MTT predictions $\left(E S_{X}\right)$ we need to elaborate equation (2) by introducing a dummy variable for China versus CEE and an interaction variable between this dummy variable and the variable year. This elaborated model appears as the dotted lines in Figure 1 and can be written as follows:

$$
E S_{X}=\beta_{0}+\beta_{1} \text { China }+\beta_{2} \text { Year }+\beta_{3} \text { China } * \text { Year }
$$

This meta-regression model enables us to determine changes in the effect sizes over time, indicated by the significance of coefficient $\beta_{2}$. We can also determine whether the effect sizes are different for China and CEE, indicated by the significance of coefficient $\beta_{1}$. Finally, the significance of coefficient $\beta_{3}$ indicates that changes in the effect sizes over time are different for China, compared to CEE.

The meta-regression model discussed above assumes a continuous linear relationship between the effect sizes and year. However, we hypothesize a break point (called a 'knot') at the transformation years, which suggests modeling a broken linear relationship. This can be achieved by transforming equations (2) and (3) into a spline model (Greene, 2000: 322-25): equations (4) and (5). Comparable methods have been used by Deng and Treiman (1997) and Luijkx et al., (2002). First we will give the equation for testing the power prediction. This is a straightforward extension of the standard regression equation (2) into a spline model:

$$
E S_{\text {pow }}=\beta_{0}+\beta_{1} \text { Year }+\beta_{2} D_{80} *(\text { Year }-1980)
$$

where, $D_{80}=1$ if year $\geq 1980$ and 0 if year $<1980$. 


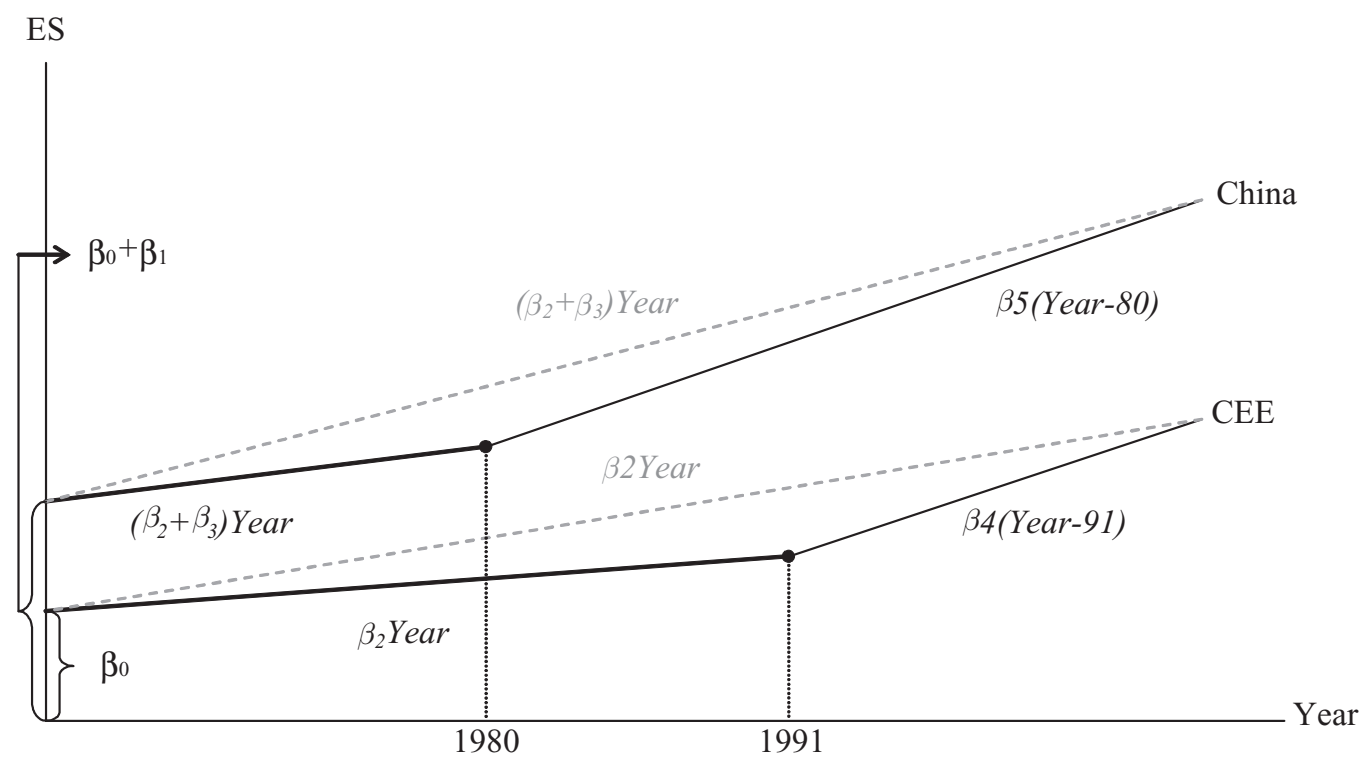

Figure 1 Illustration of spline functions

In equation (4), coefficient $\beta_{1}$ refers to the increase or decrease of the weighted mean effect size by one year in the period before 1980 . In addition, coefficient $\beta_{2}$ refers to the increase or decrease of the weighted mean effect size by one year after 1980 . So, if coefficient $\beta_{2}$ is negative or at least smaller than coefficient $\beta_{1}$ and significant, the power prediction will be confirmed.

The analyses of the other MTT predictions have an additional feature: China is compared to CEE and therefore we have two transformation years (1980 for China and 1991 for CEE). Such a model is illustrated by the continuous lines in Figure 1 and can be written as:

$$
\begin{aligned}
E S_{X}= & \beta_{0}+\beta_{1} \text { China }+\beta_{2} \text { Year }+\beta_{3} \text { China } * \text { Year } \\
& +\beta_{4} D_{91} *(1-\text { China }) *(\text { Year }-1991)+\beta_{5} D_{80} \\
& \star \text { China } *(\text { Year }-1980)
\end{aligned}
$$

where, $D_{80}=1$ if year $\geq 1980$ and 0 if year $<1980 ; D_{91}=1$ if year $\geq 1991$ and 0 if year $<1991$.

Coefficient $\beta_{1}$, in equation (5) indicates whether the effect sizes differ between China and CEE before the transformation dates. Coefficient $\beta_{2}$ indicates changes in the effect sizes before 1991 in CEE. Adding up coefficients $\beta_{2}$ and $\beta_{3}$ determines whether the effect sizes change during the period before 1980 in China. The significance of the combined effect sizes has to be determined calculating the combined variance. ${ }^{20}$ In Figure 1, the two continuous lines ending in a 'knot' represent both effects. Coefficient $\beta_{4}$ represents the changes of the effect sizes after 1991 in CEE and $\beta_{5}$ represents the changes of the effect sizes after 1980 in China. In Figure 1, the two continuous lines represent these relationships from the 'knots' onwards. If, in the case of the education prediction, coefficients $\beta_{4}$ and $\beta_{5}$ are positive and significant, this would indicate a confirmation of the MTT incentive thesis for both China and CEE. If the coefficients $\beta_{4}$ and $\beta_{5}$ are not significant, the relationship between the effect sizes and year is linear.

Finally, we include the control variables into the models. In order to keep the equations well-organized we will refer to the control variables as $Z$. The final model that will be used to test the power prediction will be made up of equation (4) extended with the set of control variables $Z$, equation (6):

$$
E S_{\text {pow }}=\beta_{0}+\beta_{1} \text { Year }+\beta_{2} D_{80} *(\text { Year }-1980)+\beta_{z} Z
$$

where, $D_{80}=1$ if year $\geq 1980$ and 0 if year $<1980$; $Z$ refers to cadre ( 1 if cadre and 0 if else), party plus cadre ( 1 if party plus cadre and 0 if else), quality ( 2 if good, 1 if medium, and 0 if poor), completeness ( 1 if all MTT variables are in the model and 0 if at least one MTT variable is missing), and published ( 1 if published and 0 if gray literature).

Equation (5) will be elaborated with control variables $Z$ making up equation (7), which describes the final 
model for testing the other MTT predictions. Five separate analyses were performed to test the incentive theses, the opportunity theses, and the gender gap hypothesis, with each model using different $Z$ variables:

$$
\begin{aligned}
E S_{X}= & \beta_{0}+\beta_{1} \text { China }+\beta_{2} \text { Year }+\beta_{3} \text { China } * \text { Year } \\
& +\beta_{4} D_{91} *(1-\text { China }) *(\text { Year }-1991)+\beta_{5} D_{80} \\
& * \text { China } *(\text { Year }-1980)
\end{aligned}
$$

Where, $D_{80}$ and $D_{91}$ are the sa me as in equation (5); $Z$ refers to transformation (1 if transformed years of education and 0 if years of education were reported), age ( 1 if age and 0 if experience) and quadratic exp. ( 1 if quadratic modeling and 0 if linear modeling), or reference sector (1 if employment in the public sector as reference category and 0 if some other sector as reference category), and quality ( 2 if good, 1 if medium, and 0 if poor), completeness ( 1 if all MTT variables are in the model and 0 if at least one MTT variable is missing), and published ( 1 if published and 0 if gray literature).

\section{Results}

For analyzing our data we use modified weighted least squares regression models, with an inverse variance weight combining the random effect component of the excess variability with fixed slopes. The method offers the possibility to model the excess variability in effect sizes. Because the effect sizes are distributed over time, excess variability may be produced by changing effects of determinants of income through time and therefore provide a test of the MTT predictions. ${ }^{21}$ Furthermore, excess variability in effect sizes may be caused by differences between studies (design, coding, models, etc.). Using this technique, we are able to present empirical results on changing effects of determinants of income during transformation processes controlled for differences between studies.

We estimated three regression models within each analysis. The 'empty model' (with only the constant) estimates the weighted mean effect size regardless of the differences between studies. ${ }^{22}$ The 'basic model' estimates changes in effect sizes before and during transformation for China and CEE, which is a blunt test of our hypothesis. The 'controlled model' estimates changes in effect sizes before and during transformation, controlled for differences between studies. These models are estimated for the six MTT determinants of income separately, using the 'METAREG'-macro (Lipsey and Wilson, 2001). The macro has several options. We used the mixed effects model with the restricted maximum likelihood procedure (REML), which leaves room for modeling part of the excess variability randomly. Furthermore, this method deals with the problem of the unequal-spaced observation point resulting in potential missing information in our data set.

\section{The Market Power Thesis}

Table 2 presents the results of the analysis of the market power thesis. The empty model shows that the pooled effect size, based on 59 observations, is significantly larger than zero. During the period of investigation (1960 to 2000), being a member of the communist party provided advantages in terms of income, compared to non-members. The basic model shows a significant negative coefficient of year and a significant positive coefficient of the 'spline'-interaction. This means that the income returns of political capital in China seem to decline during the Moa period and after that, when market reforms were introduced, political capital tends to increase income advantages of party members. For an example of the interpretation of the coefficients from the meta-regression model, we refer to Appendix A.

Introducing variables controlling for differences between studies does not change these results. Although the studies investigating income advantages of cadres report significantly higher coefficients than those investigating the income advantages of party members, our results are not being influenced by the fact that the power thesis has been tested comparing different conceptualizations. This gives some indication that despite the different conceptions of political capital, both have comparable trends over time. None of the other control variables are significant, indicating that the differences between studies do not influence the results. Based on these results we find no evidence to support the power thesis proposed by the MTT for China. $^{23}$

\section{The Market Incentive Thesis}

Human capital is operationalized in terms of returns to years of education and returns to years of experience. The results of the analysis concerning the effect of years of education on income are presented in Table 3. The empty model indicates that the pooled effect size, based on 174 observations, is significantly larger than zero. During the period under investigation (1960 to 2001), each additional year of education increased one's income. The basic model shows that the effect sizes for China are significantly smaller than those for CEE. 
Table 2 Unstandardized coefficients from the meta-regression of the effect sizes of party membership or cadre on (In)income by periods and study differences for urban China

\begin{tabular}{|c|c|c|c|}
\hline Independent variables & Empty model & Basic model & Controlled model \\
\hline \multicolumn{4}{|l|}{ Hypothesis test } \\
\hline Constant & $\begin{array}{l}0.073^{\star * \star} \\
(0.005)\end{array}$ & $\begin{array}{l}0.053^{* * *} \\
(0.014)\end{array}$ & $\begin{array}{c}0.043^{\star} \\
(0.021)\end{array}$ \\
\hline Year80 & - & $\begin{array}{c}-0.017^{\star *} \\
(0.006)\end{array}$ & $\begin{array}{c}-0.015^{\star *} \\
(0.006)\end{array}$ \\
\hline Spline $^{a}$ & - & $\begin{array}{c}0.018^{\star *} \\
(0.006)\end{array}$ & $\begin{array}{c}0.017^{* *} \\
(0.007)\end{array}$ \\
\hline \multicolumn{4}{|l|}{ Comparability controls } \\
\hline Party + cadre $^{\mathrm{b}}$ & - & - & $\begin{array}{c}-0.002 \\
(0.012)\end{array}$ \\
\hline Cadre $^{\mathrm{b}}$ & - & - & $\begin{array}{r}0.036^{*} \\
(0.020)\end{array}$ \\
\hline Quality & - & - & $\begin{array}{c}0.051 \\
(0.032)\end{array}$ \\
\hline Completeness & - & - & $\begin{array}{c}-0.018 \\
(0.019)\end{array}$ \\
\hline Published & - & - & $\begin{array}{c}0.007 \\
(0.015)\end{array}$ \\
\hline $\mathrm{n}$ & 59 & 59 & 59 \\
\hline $\mathrm{R}^{2}$ & - & 0.10 & 0.21 \\
\hline
\end{tabular}

Note: Standard errors are shown in parentheses.

${ }^{a}$ Interaction indicating the estimated slope of ES after 1980 (see equation (4)).

${ }^{b}$ Omitted category is party: studies that use the effect of party membership on (In)income to test the power thesis.

${ }^{*} P<0.05{ }^{* *} P<0.01{ }^{* * *} P<0.001$ (one-tailed test).

Furthermore, the effect sizes for China are constant before the transformation year and increase a little during the transformation process (not significantly, however). The trend in CEE is somewhat different. There seems to be a continuous increase of returns to years of education without any change caused by the transformation process (a linear trend). For an example of the interpretation of the coefficients from the meta-regression model, we refer to Appendix A.

Introducing variables controlling for differences between studies does not change these results. However, there are significant differences between studies. Studies that use panel data or capture the transformation process using regions, time, or regional growth as covariates generate lower effect sizes than studies using cross-sectional data without using covariates to capture the transformation process. Furthermore, published studies generate lower effect sizes than studies from the gray literature and elaborated models tend to generate lower effect sizes. Finally, our transformation procedure for calculating year coefficients from the coefficients of the dummy variables for educational categories does not have a significant effect.
We also tested the market incentive thesis using returns to years of experience. The results from this analysis, based on 158 observations, are reported in Table 4 . The empty model shows that the pooled effect size of years of experience on income is significantly positive. Over the period of investigation (1960 to 2001), each year of experience increased one's income. Looking at the basic model, we see that there is no significant difference in effect sizes between China and CEE. The trend for the Chinese situation seems to be constant before 1980 and the transformation process does not seem to have an effect. In CEE, the effect sizes before 1991 slightly decrease and the transformation process seems to have a positive influence; the effect sizes increase somewhat.

The results do not change when control variables are introduced, but differences between studies do matter. Studies with a good quality generally have smaller coefficients than studies with poor quality. Studies analyzing more elaborated models also generate slightly smaller regression coefficients, as do studies that published their results compared to studies from the gray literature. 
Table 3 Unstandardized coefficients from the meta-regression of the effect sizes of education on (In)income by regions, periods, and study differences

\begin{tabular}{|c|c|c|c|}
\hline Independent variables & Empty model & Basic model & Controlled model \\
\hline \multicolumn{4}{|l|}{ Hypothesis test } \\
\hline Constant & $\begin{array}{l}0.046^{\star * *} \\
(0.002)\end{array}$ & $\begin{array}{l}0.058^{\star * *} \\
(0.004)\end{array}$ & $\begin{array}{l}0.072^{\star * *} \\
(0.005)\end{array}$ \\
\hline China & - & $\begin{array}{c}-0.044^{\star \star} \\
(0.015)\end{array}$ & $\begin{array}{l}-0.053^{\star * *} \\
(0.014)\end{array}$ \\
\hline Year91 & - & $\begin{array}{r}0.002^{\star} \\
(0.001)\end{array}$ & $\begin{array}{c}0.002^{\star} \\
(0.001)\end{array}$ \\
\hline China $\times$ year91 & - & $\begin{array}{c}-0.002 \\
(0.001)\end{array}$ & $\begin{array}{c}-0.003^{\star} \\
(0.001)\end{array}$ \\
\hline Spline China ${ }^{\mathrm{a}}$ & - & $\begin{array}{c}0.001 \\
(0.001)\end{array}$ & $\begin{array}{c}0.002 \\
(0.001)\end{array}$ \\
\hline Spline $\mathrm{CEE}^{\mathrm{b}}$ & - & $\begin{array}{l}0.000 \\
(0.002)\end{array}$ & $\begin{array}{c}-0.002 \\
(.002)\end{array}$ \\
\hline \multicolumn{4}{|l|}{ Comparability controls } \\
\hline Quality & - & - & $\begin{array}{l}-0.012^{\star * *} \\
(0.003)\end{array}$ \\
\hline Completeness & - & - & $\begin{array}{r}-0.013^{\star} \\
(0.007)\end{array}$ \\
\hline Published & - & - & $\begin{array}{l}-0.013^{\star * *} \\
(0.003)\end{array}$ \\
\hline Transformed $^{c}$ & - & - & $\begin{array}{c}0.003 \\
(0.003)\end{array}$ \\
\hline $\mathrm{n}$ & 174 & 174 & 174 \\
\hline $\mathrm{R}^{2}$ & - & 0.45 & 0.53 \\
\hline
\end{tabular}

Note: Standard errors are shown in parentheses.

${ }^{a}$ Three-way interaction effect indicating the estimated slope of ES after 1980 for China (see equation (5)).

${ }^{b}$ Three-way interaction effect indicating the estimated slope of ES after 1991 for CEE (see equation (5)).

${ }^{c}$ Control dummy variable: whether educational categories transformed into years (1) or actual years of education reported (0).

${ }^{*} P<0.05{ }^{* *} P<0.01{ }^{* * *} P<0.001$ (one-tailed test).

Quadratic modeling of experience generates larger effect sizes than modeling experience in a linear way. Finally, using age as a proxy for experience seems to be justified given its non-significant effect.

The results reported above show some evidence in favor of the market incentive thesis. However, it should be noted that we also find an indication that education was already an important determinant of income during the communist era in CEE, which is a confronting finding for the MTT.

\section{The Market Opportunity Thesis}

We only present the result concerning the private sector prediction because analysis of the few observations available for the entrepreneurship prediction did not seem fruitful. In short, the results revealed that for both China and CEE entrepreneurship is a source income advantage during the transformation process, but we did not find an increasing trend during the transformation process. The income advantages of entrepreneurs seemed smaller in China compared to CEE.

The results of the private sector prediction are reported in Table 5. This analysis is based on 57 observations. The pooled effect size for China and CEE together is significantly positive: overall, working in the private sector has an income advantage compared to working in the public sector. However, the basic model suggests that the effect sizes are smaller in China than in CEE. In fact, from introducing the coefficients in equation (5) it follows that the weighted mean effect sizes for China in 1991 (then all variables but China are zero because year was centered around 1991) are zero. We find little evidence of any changes over time. Only the coefficient of the spline for China suggests that the effect sizes increase during the transformation process.

Introducing variables controlling for differences between studies slightly changes the results. We find 
Table 4 Unstandardized coefficients from the meta-regression of the effect sizes of experience on (In)income by regions, periods, and study differences

\begin{tabular}{|c|c|c|c|}
\hline Independent variables & Empty model & Basic model & Controlled model \\
\hline \multicolumn{4}{|l|}{ Hypothesis test } \\
\hline Constant & $\begin{array}{l}0.023^{\star * *} \\
(0.001)\end{array}$ & $\begin{array}{l}0.016^{\star \star \star} \\
(0.003)\end{array}$ & $\begin{array}{c}0.003 \\
(0.004)\end{array}$ \\
\hline China & - & $\begin{array}{c}-0.011 \\
(0.019)\end{array}$ & $\begin{array}{c}-0.005 \\
(0.018)\end{array}$ \\
\hline Year91 & - & $\begin{array}{c}-0.002^{\star} \\
(0.001)\end{array}$ & $\begin{array}{l}-0.002^{* *} \\
(0.001)\end{array}$ \\
\hline China $\times$ year 91 & - & $\begin{array}{c}-0.001 \\
(0.002)\end{array}$ & $\begin{array}{c}-0.001 \\
(0.002)\end{array}$ \\
\hline Spline China ${ }^{a}$ & - & $\begin{array}{c}0.002 \\
(0.002)\end{array}$ & $\begin{array}{c}0.002 \\
(0.002)\end{array}$ \\
\hline Spline $\mathrm{CEE}^{\mathrm{b}}$ & - & $\begin{array}{c}0.003^{\star} \\
(0.001)\end{array}$ & $\begin{array}{l}0.002^{\star *} \\
(0.001)\end{array}$ \\
\hline \multicolumn{4}{|l|}{ Comparability controls } \\
\hline Quality & - & - & $\begin{array}{c}-0.004^{\star} \\
(0.002)\end{array}$ \\
\hline Completeness & - & - & $\begin{array}{c}-0.010^{\star} \\
(0.005)\end{array}$ \\
\hline Published & - & - & $\begin{array}{l}-0.006^{* *} \\
(0.002)\end{array}$ \\
\hline $\operatorname{Age}^{\mathrm{c}}$ & - & - & $\begin{array}{c}-0.002 \\
(0.003)\end{array}$ \\
\hline Quadratic exp. ${ }^{\mathrm{d}}$ & - & - & $\begin{array}{l}0.021^{* * *} \\
(0.004)\end{array}$ \\
\hline$n^{e}$ & 158 & 158 & 158 \\
\hline $\mathrm{R}^{2}$ & - & 0.11 & 0.36 \\
\hline
\end{tabular}

Note: Standard errors are shown in parentheses.

${ }^{a}$ Three-way interaction effect indicating the estimated slope of ES after 1980 for China (see equation (5)).

${ }^{b}$ Three-way interaction effect indicating the estimated slope of ES after 1991 for CEE (see equation (5)).

${ }^{c}$ Control dummy variable: whether in the original studies experience was operationalized as age (1) or as tenure (0).

${ }^{d}$ Control dummy variable: whether in the original studies experience was modeled quadratically (1) or linearly (0).

${ }^{e}$ Walder (1990) excluded because the effect sizes are outliers. This does not influence conclusions.

${ }^{*} P<0.05{ }^{* *} P<0.01{ }^{* * *} P<0.001$ (one-tailed test).

further evidence for the increasing effect of working in the private sector in China during the transformation process. There are significant differences between studies. Effect sizes of studies with a good quality generate larger coefficients than studies with a poor quality. So do effect sizes from studies published in articles and books compared to those in congresses and working papers. Finally, we see that the effect sizes of employment in the private sector reported by studies using the public sector as the reference category are smaller than the effect sizes reported in studies that use some other sector as the reference category.

In sum, the results reported above indicate some evidence in favor of the market opportunity thesis for
China. Although it is not directly referring to the MTT predictions, the market-based determinants of income discussed above generate income advantages in CEE of which we cannot indicate that they change over time.

\section{The Gender Gap Hypothesis}

The test of the gender gap hypothesis is based on 131 observations (Table 6). The empty model shows that the pooled effect size is significantly negative over the period under investigation. From 1960 to 2001, women earned less than men. The basic model shows that the gender gap in income in China is smaller than in CEE. Note that the models present the situation of 1991 
Table 5 Unstandardized coefficients from the meta-regression of the effect sizes of working in the private sector on (In)income by regions, periods, and study differences

\begin{tabular}{|c|c|c|c|}
\hline Independent variables & Empty model & Basic model & Controlled model \\
\hline \multicolumn{4}{|l|}{ Hypothesis test } \\
\hline Constant & $\begin{array}{l}0.166^{* * *} \\
(0.027)\end{array}$ & $\begin{array}{c}0.167^{\star} \\
(0.072)\end{array}$ & $\begin{array}{c}-0.028 \\
(0.082)\end{array}$ \\
\hline China & - & $\begin{array}{c}-0.207 \\
(0.181)\end{array}$ & $\begin{array}{c}-0.158 \\
(0.156)\end{array}$ \\
\hline Year91 & - & $\begin{array}{c}0.004 \\
(0.019)\end{array}$ & $\begin{array}{c}0.011 \\
(0.015)\end{array}$ \\
\hline China $\times$ year91 & - & $\begin{array}{c}-0.011 \\
(0.021)\end{array}$ & $\begin{array}{c}-0.008 \\
(0.017)\end{array}$ \\
\hline Spline China $^{\mathrm{a}}$ & - & $\begin{array}{c}0.020 \\
(0.015)\end{array}$ & $\begin{array}{r}0.022^{*} \\
(0.012)\end{array}$ \\
\hline Spline $C E E^{b}$ & - & $\begin{array}{c}0.004 \\
(0.031)\end{array}$ & $\begin{array}{c}0.036 \\
(0.025)\end{array}$ \\
\hline \multicolumn{4}{|l|}{ Comparability controls } \\
\hline Quality & - & - & $\begin{array}{l}0.238^{* * *} \\
(0.067)\end{array}$ \\
\hline Completeness & - & - & $\begin{array}{c}0.035 \\
(0.066)\end{array}$ \\
\hline Published & - & - & $\begin{array}{l}0.168^{\star *} \\
(0.058)\end{array}$ \\
\hline Reference sector ${ }^{c}$ & - & - & $\begin{array}{l}-0.181^{* *} \\
(0.058)\end{array}$ \\
\hline $\mathrm{n}$ & 57 & 57 & 57 \\
\hline $\mathrm{R}^{2}$ & - & .07 & .44 \\
\hline
\end{tabular}

Notes: Standard errors are shown in parentheses.

${ }^{a}$ Three-way interaction effect indicating the estimated slope of ES after 1980 for China (see equation (5)).

${ }^{b}$ Three-way interaction effect indicating the estimated slope of ES after 1991 for CEE (see equation (5)).

${ }^{c}$ Control dummy variable: whether the reference category was state sector (1) or another sector ( 0$)$.

${ }^{*} P<0.05{ }^{* *} P<0.01{ }^{* * *} P<0.001$ (one-tailed test).

because year is centered around 1991. The weighted mean effect size for China is negative in 1991, which does not naturally follow from the coefficients reported in the table (the explanation of how the coefficients should be interpreted described in Appendix A shows that the coefficient of the spline has to multiplied with $1991-1980=11$ years). Also, the results do not reveal any trend in the effect sizes before the transformation year for either China or CEE. During the transformation process we see a gradual increase of the gender gap in China. Although the results are not significant, the results for CEE suggest the same.

Finally, the controlled model shows that taking into account differences between studies does not change these results. Only quality has a positive significant effect. Studies with a good quality tend to generate larger effect sizes than studies with a poor quality.

We find little evidence suggesting that the income differences between men and women get smaller when market reforms are introduced in (formerly) redistributive economies. In fact, the gender gap in China gets even bigger after the introduction of market reforms. The prediction that women increase their contribution to household income (Matthews and Nee, 2000) does not seem to be applicable to urban China. In CEE also women do not seem to be to taking advantage - in terms of income - of the supposed increasing opportunities.

\section{Conclusions}

Since the late 1980s, stratification research has focused on political and economic changes in (formerly) communist countries. Many authors were, and still are, intrigued by the question of how the introduction and expansion of market mechanisms influences the stratification order. The Market Transition Theory (MTT) 
Table 6 Unstandardized coefficients from the meta-regression of the effect sizes of gender on (In)income by regions, periods, and study differences

\begin{tabular}{|c|c|c|c|}
\hline Independent variables & Empty model & Basic model & Controlled model \\
\hline \multicolumn{4}{|l|}{ Hypothesis test } \\
\hline Constant & $\begin{array}{l}-0.211^{* * *} \\
(0.009)\end{array}$ & $\begin{array}{l}-0.237^{\star * *} \\
(0.019)\end{array}$ & $\begin{array}{l}-0.273^{\star * *} \\
(0.021)\end{array}$ \\
\hline China & - & $\begin{array}{l}0.274^{\star * *} \\
(0.080)\end{array}$ & $\begin{array}{l}0.300^{\star * *} \\
(0.079)\end{array}$ \\
\hline Year91 & - & $\begin{array}{c}0.006 \\
(0.006)\end{array}$ & $\begin{array}{c}0.007 \\
(0.006)\end{array}$ \\
\hline China $\times$ year91 & - & $\begin{array}{c}0.005 \\
(0.008)\end{array}$ & $\begin{array}{c}0.007 \\
(0.008)\end{array}$ \\
\hline Spline China $^{\mathrm{a}}$ & - & $\begin{array}{c}-0.019^{\star *} \\
(0.007)\end{array}$ & $\begin{array}{l}-0.021^{\star *} \\
(0.007)\end{array}$ \\
\hline Spline $\mathrm{CEE}^{\mathrm{b}}$ & - & $\begin{array}{c}-0.005 \\
(0.009)\end{array}$ & $\begin{array}{c}-0.002 \\
(0.009)\end{array}$ \\
\hline \multicolumn{4}{|l|}{ Comparability controls } \\
\hline Quality & - & - & $\begin{array}{l}0.045^{\star *} \\
(0.015)\end{array}$ \\
\hline Completeness & - & - & $\begin{array}{c}0.033 \\
(0.034)\end{array}$ \\
\hline Published & - & - & $\begin{array}{c}0.027 \\
(0.018)\end{array}$ \\
\hline $\mathrm{n}$ & 131 & 131 & 131 \\
\hline $\mathrm{R}^{2}$ & - & 0.20 & 0.27 \\
\hline
\end{tabular}

Note: Standard errors are shown in parentheses.

${ }^{a}$ Three-way interaction effect indicating the estimated slope of ES after 1980 for China (see equation (5)).

${ }^{b}$ Three-way interaction effect indicating the estimated slope of ES after 1991 for CEE (see equation (5)).

${ }^{*} P<0.05{ }^{* *} P<0.01{ }^{* * *} P<0.001$ (one-tailed test).

describes how income attainment changes when market mechanisms are introduced in redistributive economies. Its predictions have been tested on numerous occasions, and theoretical and empirical inconsistencies are prevalent. We asked whether all this effort has resulted in a better understanding of the relationship between marketization processes and stratification outcomes. Nee and Cao (Cao and Nee, 2000, Nee and Cao, 1999, Nee and Cao, 2002) have published brief summaries of empirical studies relevant to the MTT, using a technique comparable to vote counting. We extended these summaries and attempted to improve the method of research synthesis by performing a full-fledged quantitative meta-analysis, aimed at determining (a) whether there is consistent empirical evidence for the hypothesized effects of the determinants of income, (b) which part of the MTT needs revision and/or elaboration, and (c) to what extent the MTT could be regarded as a general theory.

Given the statistical insecurities and the criticism that the original power thesis predicts a relative decline instead of an absolute decline of political capital, claiming a rejection of the power thesis may be a bold one. Although we hypothesize an absolute decline of political capital, the effect sizes are at least controlled for by years of education in the original studies. Still, our finding suggests that the income returns to political capital increased during the transformation process in urban China.

The results concerning the prediction that the income returns to human capital would increase during the transformation process are ambiguous. For urban China we find no convincing evidence that the income returns to human capital increase from the transformation year onwards. In fact, both the effects of years of education and years of experience seem to get smaller. For CEE we find clear evidence that the effect of years of experience decreased during the communist era and increased during the transformation process. But the effect of education on income seems to increase steadily even during communism. 
We want to note that the small changes we find in the returns to education could result from underestimating the effects. The difference in returns to education before and during transformation will most likely be caused by increasing returns to academic degrees and decreasing returns to some vocational degrees (Flanagan, 1998), which is poorly captured by analyzing effects of years of education on income. However, we believe that part of this effect should be visible even when analyzing the effect of years of education on income. Furthermore, the data and meta-analytic research design do not allow us to investigate the changing effect of educational degrees.

Our rather slim analysis of the entrepreneurship prediction reveals no significant changes during the transformation process, though entrepreneurs tend to have higher incomes than laborers. We have analyzed selfemployed people and entrepreneurs as one group, which is subject to discussion. It could be that there are winners and losers within this group. Entrepreneurs could be the people who benefit from the transformation and take the opportunity to follow their ambitions and start up their own business. Self-employment is a broader term that could include people that are forced into starting their own business because they cannot find a job. This could have leveled out the trend we found. Only a few of the original studies make this distinction, making it hard to judge the extent to which this will affect our results.

Income returns for people working in the private sector do not change significantly during the transformation process in CEE. However, there are income advantages to employment in the private sector compared to employment in the state sector. For urban China on the other hand we find increasing income returns to employment in the private sector.

Finally, from the analysis of the gender gap hypothesis we learn that women earn less than men do. In urban China we see an unambiguous increase of the gender gap during the transformation process. This seems in line with the suggestion that income advantages for women in certain rural areas in China are an exception. For the most part women seem to have trouble keeping up with the rapidly industrializing economy. In CEE we see a similar picture, though less convincing. In relative terms, women tend to be better off in terms of income during the communist era than during the transformation process that followed.

To some extent the MTT is able to describe the changing effects of determinant of income under processes of transformation. However, we have some suggestions about where theoretical elaboration is needed. The rejection of the hypothesized decline of political capital implies that it remains a productive source of income attainment. Critics have claimed that party members convert political assets into economic capital (Hankiss, 1990; Róna-Tas, 1994; Staniszkis, 1991), which our analysis confirms. Cadre members are more likely to have high levels of political assets and should therefore have greater income advantages. The coefficients of the effect of cadre on income are larger than the coefficients of party membership on income. Furthermore, coefficients of party membership on income tend to be smaller when the effect of cadre on income is tested simultaneously. According to some, education is supposed to be the capital-conversion mechanism that provides the politically privileged with new advantages (Bian et al., 2001; Eyal et al., 1998). Others claim that it is not the supposedly superior capital that generates material advantages. Gerber shows that for Russia, membership effects are not the reason for party members earning more than non-members - but that this is due to selection effects (Gerber, 2000, 2001). Gerber also suggests that the attributes that made people members of the communist party in the first place (such as ambition, submission to organizational discipline, or even opportunism) also give them material advantages.

One would expect that market-related resources would get more important for income attainment when market mechanisms are introduced and the private sector is expanding, but we found little evidence for this. We also found that education was already strongly correlated with income attainment during the communist era in CEE. Nor do the effects on income of experience in urban China, being an entrepreneur, and employment in the private sector in CEE increase during the transformation period.

A reason for the fact that we found little evidence for increasing returns to market-related resources could be that the transformation years are chosen rather arbitrarily and assumed to be similar for the CEE countries. This indicates that directing more attention to the conditions under which supposed changes in the effects of income determinants take place could be a fruitful way to proceed. This fits in with the ideas of Stark who suggests that the transformation process should be regarded in a historical context, where crucial political and economic decisions were already being made during the communist era (1992b). Characterizing the pretransformation period as having mixed economies (Szelényi, 1988; Walder, 1995) and assuming the existence of secondary markets alongside the redistributive economy can help to explain how the effects on income 
of human capital, entrepreneurship, and employment in the private sector are influenced. Based on types of markets and market penetration, Szelényi and Kostello (1996) address the importance of explicating the circumstances under which social actors are winners or losers. They distinguish local markets in redistributively integrated economies, socialist mixed economies, and capitalist-oriented economies. Peasants and peasantworkers are the winners in the first type of economy and redistributors are the losers. In the second type, the petty bourgeoisie, technocrats, and cadre children are the winners, and old bureaucrats and 'no-hopers' (people in desperate situations) are the losers. In the last type, technocrats and the new bourgeoisie are the winners and old bureaucrats, most workers, and 'no-hopers' are the losers. These ideas could be used to elaborate the MTT and explain the influence of the transformation process on income attainment in terms of specific circumstances. It is a way to use more objective measures to capture the transformation process, rather than using only time as a proxy for transformation. This could be achieved by focusing on cross-country comparative analysis.

Elaboration is also needed to look at how gender differences in income are influenced by the transformation process. Although Matthews and Nee (2000) find evidence in favor of the MTT under specific conditions in rural China, the interrelated theses do suggest that the gender income gap would decrease when markets are introduced and expanding. Beyond rural China there seems to be little evidence for that. Differences between men and women in the employment sector and occupations can be expected to play a major role in the income difference (Fodor, 1997). In addition, the changing opportunities and incentive structure offer women the possibility of working part-time. These ideas of different labor markets for men and women and differences in career choices between men and women could be introduced into the MTT.

The MTT has often been criticized as being teleologi$\mathrm{cal}$, assuming that the transformation process is evolving into a predetermined end state: a capitalist market economy. This suggests that the MTT is formulated as a general theory linking the process of marketization to income attainment in different contexts. We question whether this is the case as it stands at this moment. While our test only distinguishes between urban China and CEE, we notice differences between the two regions. This is not really surprising. Urban China and CEE have experienced different transformation processes. The political, economic, and social changes in CEE are considered to be fundamental and irreversible (Stern, 1998). On the other hand, the changes in China might be less dramatic (Gustafsson and Shi, 2000). The theory needs to be more sensitive to the different contexts and circumstances under which the changing effects of income determinants are taking place. The idea of partial reform (Nee, 1991) may offer a fruitful approach to providing the MTT with more sensitivity to contexts of transformation. Furthermore, taking into account the historical contexts of the different countries seems advisable. For this we can build on the 'path-dependency' propositions introduced by Stark (Stark, 1992b; Stark and Bruszt, 1998; Walder, 2003).

In short, the MTT needs to be revised and elaborated at some points if we want to use it as a general theory of transformation. There are already several suggestions for this in the literature, and these adjustments could bring the MTT to that level.

\section{Why Meta-Analysis?}

In performing this meta-regression analysis, we have been confronted with several difficulties that need critical comment. When summarizing results on income studies, it is inevitable that one has to deal with different definitions of the dependent variable (income). Some studies use salary or wage as their dependent variable, while others use total income or household income. These are different concepts, which do not appear to be comparable for summarizing study results. However, selecting studies that used $\ln$ (income) as the dependent solved this problem. We performed additional analyses to check the extent to which our results would be affected by taking total income or salary as the dependent variable. Although we found differences, the conclusions remained the same. This seems to indicate that the mechanisms described in the MTT apply to different definitions of income, making this less of a problem for our meta-analysis.

Furthermore, some studies use hourly wage and others use monthly or annual income. This could lead to situations where income of a person working in a full-time position is compared to the income of a person working part-time, without discounting the difference in hours worked. As a result, the monthly income of the full-time worker could be higher only because this person is working more hours. Because we are interested in trends over time, this is a problem, especially when there is an increase in part-time positions during the transformation process.

Finally, the comparison of effect sizes between countries and over time results in comparability differences 
because of different currencies and different inflation rates. We looked at the extent to which the different currencies could influence our study outcomes by incorporating dummy variables for CEE countries. Although the coefficients of some of these dummy variables were significant, the final conclusions did not change. And while taking inflation rates into account is problematic, we can estimate the influence of inflation and adjust our conclusions accordingly. Because of inflation, effect sizes tend to be overestimated.

Besides the problems with analyzing income, studies differ with respect to the quality of the data and research design, the complexity of the analytical models, and operationalization of corresponding variables. Metaregression analysis allows for estimating the influence these differences have on our study outcomes. It at least gives insight into the extent to which these differences influence the comparison of empirical results. This can be helpful for interpreting the results of studies already performed and provide clues on how to refine future analyses. There seems to be a tendency for analyses based on cross-sectional data (without capturing the transformation process using covariates) to underestimate the effects of determinants of income. For future research, this implies that in one way or another, the transformation period has to be incorporated into the design because requirements with respect to the quality of the data are not always easily met (generating panel data is costly in terms of both time and money).

Analyses using simple models (few variables) tend to overestimate the effects of determinants of income, and additional variables consume some of the effects of other income determinants.

Finally, studies that model experience linearly tend to overestimate the effect of years of experience on income. For more precise estimations of the changing effects of experience on income, experience should be modeled using a quadratic covariate.

We believe that these problems are distinctive when comparing research findings in the field of stratification, whether it is qualitative or quantitative. Although metaanalysis is far from perfect, we at least attempted to model the differences between studies as well as possible and investigate to what extent they influence conclusions based on summarizing empirical results.

\section{Notes}

1. The last possibility would coincide with shifts in income that would not ultimately result in a differ- ent distribution at the macro level: the rich and the poor could shift positions. However, there is consensus that macro-level distributions of income have changed.

2. We refer to Hedges and Olkin $(1980,1985)$ for a thorough elaboration of the disadvantages and deficiencies of the traditional vote-counting method.

3. Following Nee's sequence, we start with the market power thesis. The reason Nee presented this thesis first is probably due to the importance of the cadre for socioeconomic attainment in China at the time he formulated his theory.

4. Not all studies report SEs, needed for calculating the weight factor. Some report $\mathrm{t}$-values that can be used to calculate SEs and others report only p-values that can be used to estimate SEs. Studies that report no information at all on significance levels cannot be used in our meta-analysis. We determine the weight factor following the flow chart used by Wagner and Weiss (2003).

5. They speak of within-study sample size because estimates of several different studies are used.

6.

$$
S E_{\overline{E S}}=\sqrt{\frac{1}{\sum w_{i}}}
$$

7. American Journal of Sociology, American Sociological Review, Social Forces, Social Science Research, Economics of Transition, Labour Economics, Journal of Population Economics, Theory and Society, and China Quarterly, etc. Unfortunately, we are not familiar with the Chinese and Central and Eastern European languages; therefore, most studies written in the language of the country of origin were excluded. This will decrease the external validity to some extent, but we expect this bias to be reduced because of the included joint publications of foreign and native authors.

8. Google searches were made on 'market transition' and within results on 'income'. Sociological Abstracts and EconLit were also searched under 'market transition' and 'income'.

9. From here on, if we use income, it should be read $\ln$ (income).

10. Based on descriptive statistics not shown here, the income advantages of party members, having more experience, entrepreneurship, employment in the private sector, and males tend to be higher in rural than in urban areas. Only income returns to years 
of education seem higher in urban than in rural areas.

11. The countries are: China $(\mathrm{N}=31)$; Russia $(\mathrm{N}=12)$; Hungary $(\mathrm{N}=5)$; Czech Republic $(\mathrm{N}=10)$; Poland $(\mathrm{N}=6)$; East Germany $(\mathrm{N}=7)$; Slovak Republic $(\mathrm{N}=5)$; Slovenia $(\mathrm{N}=1)$; Bulgaria $(\mathrm{N}=3)$; Latvia $(\mathrm{N}=1)$; Ukraine $(\mathrm{N}=1)$; Uzbekistan $(\mathrm{N}=1)$; Yugoslavia $(\mathrm{N}=1)$; Kazakhstan $(\mathrm{N}=1)$; Romania $(\mathrm{N}=1)$.

12. The variables names printed in bold are the variables used in the original publications; the variables names printed in italics are variables used in the meta-analysis.

13. Walder (1990) was excluded (only) from the analysis of the incentive prediction (experience), because the ES were outliers, which could disturb the outcomes (Hedges and Olkin, 1985).

14. We analyzed correlations between the dummy variables for educational levels for several countries using the 'Social Stratification in Eastern Europe: After 1989' project (Szelényi and Treiman, 1994). The average correlation coefficient between the educational dummy variables for each country is about 0.33 , so assuming a fixed correlation of 0.35 seems reasonable. In our estimating procedure, we also varied the correlation between the educational dummy variables, but this did not have a large influence on the transformed 'educational year' coefficients.

15. A proxy for experience can be estimated by the conventional formula: experience $=($ age - years of schooling -6) (Treiman and Roos, 1983).

16. The effect sizes for testing the 'entrepreneurship' hypothesis are an exception: they range from 1978 to 2000 .

17. In the tables, year has been centered around 1991. This is helpful when interpreting the coefficients of main effects and it reduces collinearity.

18. The majority of studies implicitly assume that more recent periods correspond to a higher degree of marketization. We found two different ways in which the transformation has been taken into account more explicitly: first, some researchers have used time as a covariate. Second, regional growth is used to capture the transition period.

19. Estimate a modified weighted least squares regression model, with an inverse variance weight that incorporates the random effects component.

20. VAR $\left(\beta_{2}+\beta_{3}\right)=\operatorname{VAR}\left(\beta_{2}\right)+\operatorname{VAR}\left(\beta_{3}\right)+2 \operatorname{COV}\left(\beta_{2}\right.$, $\left.\beta_{3}\right) ; S E=\sqrt{\operatorname{VAR}\left(\beta_{2}+\beta_{3}\right)}$. A t-test can be used to determine the significance.
21. An ANOVA analysis - comparing before with during the transformation - shows that the weighted mean effect sizes are significantly different between the two periods. (Table available on request.) The ANOVA gives an idea of potential changes in the effects of determinants of income under processes of transformation, but it cannot deal with differences between studies and may result in misleading conclusions when effect sizes are compared through time.

22. Based on the analyses of the weighted mean effect sizes, homogeneity has to be rejected, meaning that the variability across effect sizes is greater than expected from sampling error alone. (Table available on request.)

23. Descriptive analyses (scatterplots) on the few CEE studies suggest the same.

\section{Acknowledgements}

Earlier versions of this paper were presented at the summer meeting of the International Sociological Association Research Committee on Social Stratification (RC28), New York, August 2003; and the UW-Madison Demography and Ecology Seminar, October 26, 2004. We thank the participants at these meetings and colleagues at the ICS for helpful feedback, Donald Treiman for his comments and suggestions as an RC28 referee, several anonymous reviewers for their comments, and Harry Ganzeboom and Henk Flap for their extensive suggestions on earlier versions. We thank Jeroen Weesie for writing a Stata-program to estimate the coefficient of the effect of years of education based on the coefficients of the dummy variables.

\section{References}

Atkinson, A. B. and Micklewright, J. (1992). Economic Transformation in Eastern Europe and the Distribution of Income. Cambridge: Cambridge University Press.

Becker, G. S. (1993). Human Capital. A Theoretical and Empirical Analysis, with Special Reference to Education (Third Edition). Chicago: The University of Chicago Press.

Bian, Y. (2002). Chinese Social Stratification and Social Mobility. Annual Review of Sociology, 28, 91-116.

Bian, Y., Shu, X. and Logan, J. R. (2001). Communist Party Membership and Regime Dynamics in China. Social Forces, 79, 805-841.

Blanchard, O. J., Froot, K. A. and Sachs, J. D. (1994). Introduction to the Transition in Eastern Europe. Chicago: University of Chicage Press. 
Cao, Y. and Nee, V. (2000). Comment: Controversies and Evidence in the Market Transition Debate. American Journal of Sociology, 105, 1175-1189.

Cao, Y. and Nee, V. (2002). Remaking Inequality: Market Expansion and Income Stratification in Reforming State Socialism. Louisiana: Louisiana State University.

Cooper, H. M. (1982). Scientific Guidlines for Conducting Integrative Research Reviews. Review of Educational Research, 52, 291-302.

Deng, Z. and Treiman, D. J. (1997). The Impact of the Cultural Revolution on Trends in Educational Attainment in the People's Republic of China. American Journal of Sociology, 103, 391-428.

Dessens, J. A. G., Jansen, W. and Nelissen, J. H. M. (1998). Income Inequality and Income Determinants in Eastern Europe Before and After 1989. In Nieuwbeerta, P. and Ganzeboom, H. B. G. (Eds) Conference Transformation Processes in Eastern Europe. Part II Social Stratification. The Hague: ESR, pp. 41-56.

Domanski, H. and Heyns, B. (1995). Toward a Theory of the Role of the State in Market Transition: From Bargaining to Markets in Post-Communism. European Journal of Sociology (Archives Européennes de Sociologie), 36, 317-351.

Eyal, G., Szelényi, I. and Townsley, E. (1998). Making Capitalism Without Capitalists. The New Ruling Elites in Eastern Europe. London: Verso.

Fabig, H. (1999). Einkommensdynamik im Internationalen Vergleich. Eine Empirische Mobilitätsanalyse mit Panel-Daten. Frankfurt/Main: Campus Verlag.

Flanagan, R. J. (1998). Were Communists Good Human Capitalists? The Case of the Czech Republic. Labour Economics, 5, 295-312.

Flemming, J. S. and Micklewright, J. (1999). Income Distribution, Economic Systems and Transition. In Atkinson, A. B. and Bourguignon, F. (Eds) Handbook of Income Distribution. Amsterdam: Elsevier Science, pp. 843-918.

Fligstein, N. (1996). The Economic Sociology of the Transitions from Socialism. American Journal of Sociology, 101, 1074-1081.

Fodor, E. (1997). Gender in Transition: Unemployment in Hungary, Poland, and Slovakia. East European Politics and Societies, 11, 470-500.

Ganzeboom, H. B. G. (1998). Social Stratification in Eastern Europe: The Dutch View. In Nieuwbeerta, P. and Ganzeboom, H. B. G. (Eds) Conference Transformation Processes in Eastern Europe. Part II Social Stratification. The Hague: ESR, pp. 227-240.

Gerber, T. P. (2000). Membership Benefits or Selection Effects? Why Former Communist Party Members Do Better in Post-Soviet Russia. Social Science Research, 29, 25-50.

Gerber, T. P. (2001). The Selection Theory of Persisting Party Advantages in Russia: More Evidence and Implications. Social Science Research, 30, 653-671.
Gerber, T. P. and Hout, M. (1998). More Shock than Therapy: Market Transition, Employment, and Income in Russia, 1991-1995. American Journal of Sociology, 104, 1-50.

Glass, G. V., McGaw, B. and Smith, M. L. (1981). MetaAnalysis in Social Research. Beverly Hills, CA: Sage Publications, Inc.

Greene, W. H. (4 $\left.{ }^{\text {th }}\right)$ (2000). Econometric Analysis. New Jersey: Prentice-Hall, Inc.

Griffin, K. and Renwei, Z. (1993). The Distribution of Income in China. New York: St. Martin's Press.

Gustafsson, B. and Shi, L. (2000). Economic Transformation and the Gender Earnings Gap in Urban China. Journal of Population Economics, 13, 305-329.

Hall, J. A., Rosenthal, R., Tickle-Degnen, L. and Mosteller, F. (1994). Hypotheses and Problems in Research Synthesis. In Cooper, H. M. and Hedges, L. V. (Eds) The Handbook of Research Synthesis. New York: Russel Sage Foundations.

Hankiss, E. (1990). East European Alternatives. Oxford: Clarendon Press.

Hanley, E. and Treiman, D. J. (2001). Dual Career Paths into the Eastern European Communist Elite. Presented at the Research Commitee on Social Stratification and Mobility (RC28), Berkeley.

Hauser, S. M. and Xie, Y. (2001). Temporal and Regional Variation in Earnings Inequality: Urban China in Transition between 1988 and 1995. Presented at the Research Commitee on Social Stratification and Mobility (RC28), Berkeley.

Hedges, L. V. and Olkin, I. (1980). Vote Counting Methods in Research Synthesis. Psychological Bulletin 88, 359-369.

Hedges, L. V. and Olkin I. (1985). Statistical Methods for Meta-Analysis. Orlando, FL: Academic Press. Inc.

Hunter, J. E. and Schmidt, F. L. (1990). Methods of Meta-Analysis. Correcting Error and Bias in Research Findings. Newbury Park, CA: Sage Publications, Inc.

Hunter, J. E., Schmidt, F. L. and Jackson, G. B. (1982). Meta-Analysis. Cumulative Research Findings Across Studies. Beverly Hills, CA: Sage Publications, Inc.

Khan, A. R., Griffin, K., Riskin, C. and Renwei, Z. (1992). Household Income and Its Distribution in China. The China Quarterly, 132, 1029-1061.

Kropp, P. B. (1998). Berufserfolg im Transformationsprozess. Eine Theoretisch-Empirische Studie über die Gewinner und Verlierer der Wende in Ostdeutschland. Utrecht: ICS Dissertation Series.

Light, R. J. and Smith, P. V. (1971). Accumulating Evidence: Procedures for Resolving Contradictions among Different Research Studies. Harvard Educational Review, 41, 429-471.

Lipsey, M. W. and Wilson, D. B. (2001). Practical MetaAnalysis. Thousand Oaks, CA: Sage Publications, Inc. 
Luijkx, R., Róbert, P., de Graaf, P. M. and Ganzeboom, H. B. G. (2002). Changes in Status Attainment in Hungary Between 1910 and 1989. European Societies, 4, 107-140.

Mateju, P. and Reháková, B. (1996). Education as a Strategy for Life Success in the Postcommunist Transformation: The Case of the Czech Republic. Comparative Education Research, 40, 158-176.

Matthews, R. and Nee, V. (2000). Gender Inequality and Economic Growth in Rural China. Social Science Research, 29, 606-632.

Mincer, J. (1958). Investment in Human Capital and Personal Income Distribution. Journal of Political Economy, 66, 281-302.

Nee, V. (1989). A Theory of Market Transition: From Redistribution to Markets in State Socialism. American Sociological Review, 54, 663-681.

Nee, V. (1991). Social Inequality in Reforming State Socialism: Between Redistribution and Markets in China. American Sociological Review, 56, 267-282.

Nee, V. (1996). Symposium on Market Transition. The Emergence of a Market Society: Changing Mechanisms of Stratification in China. American Journal of Sociology, 101, 908-949.

Nee, V. and Cao, Y. (1999). Path Dependent Societal Transformation: Stratification in Hybrid Mixed Economies. Theory and Society, 28, 799-834.

Nee, V. and Cao, Y. (2002). Postsocialist Inequalities: The Causes of Continuity and Discontinuity. In Leicht, K. T. (Ed.) The Future of Market Transition. Kidlington: Elsevier Science, pp. 3-39.

Nee, V. and Liedka, R. V. (1997). Markets and Inequality in the Transition from State Socialism. In Midlarsky, M. I. (Ed.) Inequality, Democracy, and Economic Development. Cambridge: Cambridge University Press, pp. 202-224.

Nee, V. and Matthews, R. (1996). Market Transition and Societal Transformation in Reforming State Socialism. Annual Review of Sociology, 22, 401-435.

Oberschall, A. (1996). The Great Transition: China, Hungary and Sociology Exit Socialism into the Market. American Journal of Sociology, 101, 1028-1041.

Ogloblin, C. G. (1999). The Gender Earnings Differential in the Russian Transition Economy. Industrial and Labor Relations Review, 52, 602-627.

Orazem, P. F. and Vodopivec, M. (1995). Winners and Losers in Transition: Returns to Education, Experience, and Gender in Slovenia. The World Bank Economic Review, 9, 201-230.

Orazem, P. F. and Vodopivec, M. (2000). Male-Female Differences in Labor Market Outcomes During the Early Transition to Market: The Cases of Estonia and Slovenia. Population Economics, 13, 283-303.

Parish, W. L. and Michelson, E. (1996). Politics and Markets: Dual Transformations. American Journal of Sociology, 101, 1042-1059.
Peng, Y. (1992). Wage Determination in Rural and Urban China: A Comparison of Public and Private Industrial Sectors. American Sociological Review, 57, 198-213.

Róna-Tas, Á. (1994). The First Shall Be Last? Entrepreneurship and Communist Cadres in the Transition from Socialism. American Journal of Sociology, 100, 40-69.

Rosenthal, R. and Rubin, D. B. (1978). Interpersonal Expectancy Effects: The First 345 studies. The Behavioral and Brain Sciences, 3, 377-415.

Schmidt, F. L. and Hunter, J. E. (1977) Development of a General Solution to the Problem of Validity Generalization. Journal of Applied Psychology, 62, 529-540.

Schultz, T. W. (1963). The Economic Value of Education. New York: Columbia University Press.

Shadish, W. R. and Haddock, C. K. (1994). Combining Estimates of Effects Size. In Cooper, H. M. and Hedges, L. V. (Eds) The Handbook of Research Synthesis. New York: Russell Sage Foundation, pp. 261-281.

Smith, M. L. and Glass, G. V. (1977). Meta-Analysis of Psychotherapy Outcome Studies. American Psychologist, 32, 752-760.

Snijders, T. A. B. (1997). De Populaties van de MetaAnalyse. Tijdschrift voor Onderwijsresearch, 22, 3-15.

Staniszkis, J. (1991). The Dynamics of Breakthrough in Eastern Europe. Berkeley: University of California Press.

Stark, D. (1992a). From System Identity to Organizational Diversity: Analysing Social Change in Eastern Europe. Contemporary Sociology, 21, 299-304.

Stark, D. (1992b). Path Dependence and Privatization Strategies in East Central Europe. East European Politics and Societies, 6, 17-54.

Stark, D. (1996). Recombinant Property in East European Capitalism. American Journal of Sociology, 101, 993-1027.

Stark, D. and Bruszt, L. (1998). Postsocialist Pathways. Transforming Politics and Property in East Central Europe. Cambridge: Cambridge University Press.

Stern, N. (1998). The Future of the Economic Transition. London: EBRD.

Szelényi, I. (1988). Socialist Entrepreneurs: Embourgeoisement in Rural Hungary. Madison: University of Wisconsin Press.

Szelényi, I. and Kostello, E. (1996). The Market Transition Debate: Towards a Synthesis? American Journal of Sociology, 101, 1082-1096.

Szelényi, I. and Treiman, D. J. (1994). Social Stratification in Eastern Europe after 1989: General Population Survey. Provisional Codebook.

Treiman, D. J. and Roos, P. A. (1983). Sex and Earnings in Industrial Society: A Nine-Nation Comparison. American Journal of Sociology, 89, 612-650.

Wagner, M. and Weiss, B. (2003). Bilanz der Deutschen Scheidungsforschung. Versuch einer Meta-Analyse. Zeitschrift für Soziologie, 32, 29-49. 
Walder, A. G. (1990). Economic Reform and Income Distribution in Tianjin, 1976-1986. In Davis D. and Vogel E. F. (eds), Chinese Society on the Eve of Tiananmen. The Impact of Reform. Cambridge, MA: Harvard University Press, pp. 135-156.

Walder, A. G. (1995). Career Mobility and the Communist Political Order. American Sociological Review, 60, 309-328.

Walder, A. G. (1996). Markets and Inequality in Transitional Economies: Towards Testable Theories. American Journal of Sociology, 101, 1060-1073.

Walder, A. G. (2002). Markets and Income Inequality in Rural China: Political Advantage in an Expanding Economy. American Sociological Review, 67, 231-253.

Walder, A. G. (2003). Elite Opportunity in Transitional Economies. American Sociological Review, 68, 899-916.

White, H. D. (1994). Scientific Communication and Literature Retrieval. In Cooper, H. M. and Hedges, L. V. (Eds) The Handbook of Research Synthesis. New York: Russel Sage Foundation, pp. 41-55.

Xie, Y. and Hannum, E. (1996). Regional Variation in Earnings Inequality in Reform-Era Urban China. American Journal of Sociology, 101, 950-992.

$\mathrm{Xu}$, L. C. and Zou, H. F. (2000) Explaining the Changes of Income Distribution in China. China Economic Review, 11, 149-170.

Zhou, X. (2000). Economic Transformation and Income Inequality in Urban China: Evidence from Panel Data. American Journal of Sociology, 105, 1135-1174.

\section{Authors' Addresses}

Willem-Jan Verhoeven (to whom correspondence should be addressed), Department of Sociology/ICS, Utrecht University, Heidelberglaan 2, 3584 CS Utrecht, The Netherlands. Email: w.j.verhoeven@fss.uu.nl

Wim Jansen, Department of Methodology and Statistics/ICS, Utrecht University, Heidelberglaan 2, 3584 CS Utrecht, The Netherlands.

Jos Dessens, Department of Methodology and Statistics/ ICS, Utrecht University, Heidelberglaan 2, 3584 CS Utrecht, The Netherlands.

Manuscript received: October 2004.

\section{Appendix A}

\section{Example 1: Interpretation of Coefficients from the Power Analysis}

We introduce the coefficients of the basic model, reported in Table 2 , in equation (4):

$$
E S_{\text {pow }}=0.053-0.017 * \text { Year }+0.018 \mathrm{D}_{80} *(\text { Year }-1980)
$$

During the period before 1980 the constant decreases with 0.017 for each additional year. This can derived from the way $D_{80}$ has been coded (' 1 ' if year $\geq 1980$ and ' 0 ' if year $<1980$ ).

$$
\text { Before: } \quad E S_{\text {pow }}=0.053-0.017 * \text { Year }
$$

If we look at the period after 1980 the spline-component is introduced; $D_{80}$ is one. Note that (Year-1980) starts counting after 1980, indicating that after 1980 each additional year increases the constant with $-0.017+0.018=0.001$ compared to a 0.017 decrease of the constant for each additional year before 1980 .

After: $E S_{\text {pow }}=0.053-0.017^{*}$ Year $+0.018^{*}($ Year -1980$)$

\section{Example 2: Interpretation of Coefficients from the Education Analysis}

We introduce the coefficients of the basic model, reported in Table 3 , in equation (5)

$$
\begin{aligned}
E S_{\text {educ }}= & 0.058-0.044 * \text { China }+0.002 * \text { Year } \\
& -0.002 * \text { China } * \text { Year }+0.001 * \mathrm{D}_{91} \\
& \star(1-\text { China }) *(\text { Year }-1991)+.000 * \mathrm{D}_{80} \\
& \star \text { China } *(\text { Year }-1980)
\end{aligned}
$$

During the period before 1980 in China an additional year does not change the constant: $0.002-0.002=0$. This can derived from the way China (' 1 ' if China and ' 0 ' if CEE) and $D_{80}$ have been coded (' 1 ' if year $\geq 1980$ and ' 0 ' if year < 1980). During the period before in CEE an additional year increases the constant with 0.002 . Given the way China and $D_{91}$ have been coded (' 1 ' if year $\geq 1991$ and ' 0 ' if year $<1991$ ). In both situations the splinecomponents are eliminated from the equation.

$$
\text { China before: } \begin{aligned}
E S_{e d u c}= & (0.058-0.044) \\
& +(0.002-0.002) * \text { Year }
\end{aligned}
$$

CEE before: $\quad E S_{e d u c}=0.058+0.002 *$ Year

For the period after 1980 in China and the period after 1991 in CEE the spline-components are introduced (respectively $D_{80}$ and $D_{91}$ are one). Note that (Year1980) starts counting after 1980 and that (Year-1991) starts counting after 1991. This indicates that, in China, after 1980 each additional year increases the constant with $0.002-0.002+0.001=0.001$ compared to no changes of the constant for each additional year before 1980. For CEE this leads to the same increase of $0.002+$ 
$0.000=0.002$ for each additional year as for the period before 1991 .

$$
\text { China after: } \begin{aligned}
E S_{\text {educ }}= & (0.058-0.044)+(0.002 \\
& -0.002+0.001) * \text { Year }
\end{aligned}
$$

$$
\text { CEE after: } \quad E S_{\text {educ }}=0.058+(0.002+0.000) * \text { Year }
$$

Note that year is a variable constructed by subtracting 1960 from the actual years and that it has been centered around 1991. This means 1991 is actually zero and that 1980 is actually -11 . Introducing this information into the equation for China results in the following mean effect size for year 1991 .

$$
\text { China 1991: } \begin{aligned}
E S_{\text {educ }}= & (0.058-0.044)+(0.001) \\
& \star 11=0.025
\end{aligned}
$$

\section{Appendix B}

\section{References Selected for the Meta-Analysis}

Adamchak, D. J., Chen, S. and Li, J. (1999). Occupations, Work Units, and Work Rewards in Urban China. International Sociology, 14, 423-441.

Bartus, T. (2001). Social Capital and Earnings Inequalities. The Role of Informal Job Search in Hungary. Groningen: ICS, University of Groningen.

Bian, Y. and Logan, J. R. (1996). Market Transition and the Persistence of Power: The Changing Stratification System in Urban China. American Sociological Review, 61, 739-758.

Bian, Y. and Zhang, Z. (2002) Marketization and Income Distribution in Urban China, 1988 and 1995. In Leicht, K. T. (Ed.) The Future of Market Transition. Kidlington: Elsevier Science, pp. 377-415.

Bird, E. J., Schwarze, J. and Wagner, G. G. (1994). Wage Effects of the Move Towards Free Markets in East Germany. Industrial and Labor Relations Review, 47, 390-400.

Böröcz, J. and Southworth, C. (1996). Decomposing the Intellectuals' Class Power: Conversion of Cultural Capital to Income, Hungary, 1986. Social Forces, 74, 797-821.

Brainerd, E. (1998). Winners and Losers in Russia's Economic Transition. American Economic Review, 88, 1094-1116.

Brainerd, E. (2002). Five Years After: The Impact of Mass Privatization on Wages in Russia, 1993-1998. Journal of Comparative Economics, 30, 160-190.

Byron, R. P. and Manaloto, E. Q. (1990). Returns to Education in China. Economic Development and Cultural Change, 38, 783-796.

Campos, N. F. and Jolliffe, D. (2002). After, Before and During: Returns to Education in the Hungarian
Transition. Michigan: The William Davidson Institute.

Cao, Y. and Nee, V. (2002). Remaking Inequality: Market Expansion and Income Stratification in Reforming State Socialism. Louisiana: Louisiana State University.

Chase, R. S. (1998). Markets for Communist Human Capital: Returns to Education and Experience in the Czech Republic and Slovakia. Industrial and Labor Relations Review, 51, 401-423.

Cio, Y. (2001). Careers Inside Organizations: A Comparative Study of Promotion Determination in Reforming China. Social Forces, 80, 683-712.

Dickson, B. J. and Rublee, M. R. (2000). Membership Has Its Privileges. The Socioeconomic Characteristics of Communist Party Members in Urban China. Comparative Political Studies, 33, 87-112.

Diewald, M. and Mach, B. W. (1999) Market Transition, Institutions, and the Restructuring of Earnings: East Germany and Poland During the First Five Years of the Transformation Process. Berlin: Max-PlanckInstitut für Bildungsforschung.

Domanski, H. and Heyns, B. (1995). Toward a Theory of the Role of the State in Market Transition: From Bargaining to Markets in Post-Communism. European Journal of Sociology (Archives Européennes de Sociologie), 36, 317-351.

Filer, R. K., Jurajda, S. and Plánovský, J. (1999). Education and Wages in the Czech and Slovak Republics During Transition. Labour Economics, 6, 581-93.

Flanagan, R. J. (1998). Were Communists Good Human Capitalists? The Case of the Czech Republic. Labour Economics, 5, 295-312.

Gerber, T. P. (2000). Membership Benefits or Selection Effects? Why Former Communist Party Members Do Better in Post-Soviet Russia. Social Science Research, 29, 25-50.

Gerber, T. P. (2001). The Selection Theory of Persisting Party Advantages in Russia: More Evidence and Implications. Social Science Research, 30, 653-671.

Gerber, T. P. and Mayorova, O. (2003). Getting Personal: The Use of Networks For Successful Job Searches in Russia, 1985-2001. Presented at the Research Commitee on Social Stratification and Mobility (RC28), Tokyo.

Glinskaya, E. and Mroz, T. A. (2000). The Gender Gap in Wages in Russia from 1992 to 1995. Journal of Population Economics, 13, 353-386.

Gustafsson, B. and Shi, L. (2000). Economic Transformation and the Gender Earnings Gap in Urban China. Journal of Population Economics, 13, 305-329.

Hanley, E. (2000) Self-Employment in Post-Communist Eastern Europe: A Refuge from Poverty or Road to Riches? Communist and Post-Communist Studies, 33, 379-402.

Hauser, S. M. and Xie, Y. (2001). Temporal and Regional Variation in Earnings Inequality: Urban China in 
Transition between 1988 and 1995. Presented at the Research Commitee on Social Stratification and Mobility (RC28), Berkeley.

Hunt, J. (1997). The Transition in East Germany: When is a Ten Point Fall in the Gender Wage Gap Bad News? Cambridge: National Bureau of Economic Research.

Jolliffe, D. (2002). The Gender Wage Gap in Bulgaria: A Semiparametric Estimation of Discrimination. Journal of Comparative Economics, 30, 276-295.

Jurajda, Š. (2003). Gender Wage Gap and Segregation in Enterprises and the Public Sector in Late Transition Countries. Journal of Comparative Economics, 31, 199-222.

Keane, M. and Prasad, E (1999). Consumption and Income Inequality in Poland During the Economic Transition. Washington: International Monetary Fund (IMF).

Knight, J. and Song, L. (2001). Economic Growth, Economic Reform, and Rising Inequality in China. In Riskin, C., Renwei, Z. and Shi, L. (Eds) China's Retreat from Equality. Income Distribution and Economic Transition. Armonk, N.Y.: M. E. Sharp, pp. 84-121.

Kostello, E. (2002). Inequality and Market Transition. Presented at the American Sociological Association, Chicago.

Krueger, A. B. and Pischke, J.-S. (1995). A Comparative Analysis of East and West German Labor Markets: Before and After Unification. In Freeman, R. B. and Katz, L. F. (Eds) Differences and Changes in Wage Structures. Chicago: The University of Chicago Press, pp. 405-445.

Li, H. (2003). Economic Transition and Returns to Education in China. Economics of Education Review. 22, 317-328.

Liu, P.-W., Meng, X. and Zhang, J. (2000). Sectoral Gender Wage Differentials and Discrimination in the Transitional Chinese Economy. Journal of Population Economics, 13, 331-352.

Liu, Z. (1998). Earnings, Education, and Economic Reforms in Urban China. Economic Development and Cultural Change, 46, 697-725.

Maurer-Fazio, M. (1999). Earnings and Education in China's Transition to a Market Economy. Survey Evidence from 1989 and 1992. China Economic Review, 10, 17-40.

Meng, X. and Kidd, M.P. (1997). Labor Market Reform and the Changing Structure of Wage Determination in China's State Sector during the 1980s. Journal of Comparative Economics, 25, 403-421.

Munich, D., Svejnar, J. and Terrell, K. (2002). Returns to Human Capital Under the Communist Wage Grid and During the Transition to a Market Economy. Michigan: The William Davidson Institute.

Newell, A. and Reilly, B. (1996). The Gender Gap in Russia: Some Empirical Evidence. Labour Economics, 3, 337-356.
Newell, A. and Reilly, B. (2000) The Gender Pay Gap in the Transition from Communism: Some Empirical Evidence. Michigan: The William Davidson Institute.

Orazem, P. F. and Vodopivec, M. (1995). Winners and Losers in Transition: Returns to Education, Experience, and Gender in Slovenia. The World Bank Economic Review, 9, 201-230.

Peng, Y. (1992). Wage Determination in Rural and Urban China: A Comparison of Public and Private Industrial Sectors. American Sociological Review, 57, 198-213.

Raymo, J. M. and Xie, Y. (2000). Income of the Urban Elderly in Postreform China: Political Capital, Human Capital, and the State. Social Science Research, 29, 1-24.

Reilly, B. (1999). The Gender Pay Gap in Russia During the Transition, 1992-1996. Economics of Transition, 7, 245-264.

Róna-Tas, Á. and Guseva, A. (2001) The Privileges of Past Communist Party Membership in Russia and Endogenous Switching Regression. Social Science Research, 30, 641-652.

Schwarze, J. and Wagner, G. G. (2001): Earning Dynamics in the East German Transition Process. In Riphahn, R. T., Snower, D. J. and Zimmerman, K. F. (Eds) Employment in Transition: The Lessons of German Integration for the Labor Market. Berlin: Springer, pp. 125-143.

Shu, X. and Bian, Y. (2002). Intercity Variation in Gender Inequalities in China: Analysis of a 1995 National Survey. In Leicht, K. T. (Ed.) The Future of Market Transition. Kidlington: Elsevier Science, pp. 296-309.

Shu, X. and Bian, Y (2003). Market Transition and Gender Gap in Earnings in Urban China. Social Forces, 81, 1107-1145.

Sorensen, A. and Trappe, H. (1995). The Persistence of Gender Inequality in Earnings in the German Democratic Republic. American Sociological Review, 60, 398-406.

Szydlik, M. (1994). Incomes in a Planned and a Market Economy: The Case of the German Democratic Republic and the 'Former' Federal Republic of Germany. European Sociological Review, 10, 199-217.

Vecerník, J. (1995). Changing Earnings Distribution in the Czech Republic: Survey Evidence from 19881994. Economics of Transition, 3, 355-371.

Vecerník, J. (2001). Earnings Disparities in the Czech Republic: Evidence of the Past Decade and CrossNational Comparison. Michigan: The William Davidson Institute.

Walder, A. G. (1990). Economic Reform and Income Distribution in Tianjin, 1976-1986. In Davis, D. and Vogel, E. F. (Eds) Chinese Society on the Eve of Tiananmen. The Impact of Reform. Cambridge, MA: Harvard University Press, pp. 135-156. 
Walder, A. G. (1995) Career Mobility and the Communist Political Order. American Sociological Review, 60, 309-328.

Wu, X. (2002). Work Units and Income Inequality: The Effect of Market Transition in Urban China. Social Forces, 80, 1069-1099.

Wu, X. and Xie, Y. (2003). Does the Market Pay Off? Earnings Returns to Education in Urban China. American Sociological Review, 68, 425-442.

Xie, Y. and Hannum, E. (1996). Regional Variation in Earnings Inequality in Reform-Era Urban China. American Journal of Sociology, 101, 950-992.

Zang, X. (2002). Labor Market Segmentation and Income Inequality in Urban China. The Sociological Quarterly, 43, 27-44.

Zhang, Z. (2000). Labor Institutions, State Power, and Earnings Inequality in Reforming Urban China. Hong Kong: Social Science, The Hong Kong University of Science and Technology.
Zhao, W. and Zhou, X. (2002). Institutional Transformation and Returns to Education in Urban China: An Empirical Assessment. In Leicht, K. T. (Ed.) The Future of Market Transition. Kidlington: Elsevier Science, pp. 339-375.

Zhou, W. (2001). Earnings Inequality in China's Transition Economy: A Theory of Dual Labor Market. Presented at the Research Commitee on Social Stratification and Mobility (RC28), Berkeley.

Zhou, X. (2000). Economic Transformation and Income Inequality in Urban China: Evidence from Panel Data. American Journal of Sociology, 105, 1135-1174.

Zhou, X. and Moen, P. (2001) Explaining Life Chances in China's Economic Transformation: A Life Course Approach. Social Science Research, 30, 552-577.

Zhou, X. and Suhomlinova, O. (2001) Redistribution under State Socialism: A USSR and PRC Comparison. Research in Social Stratification and Mobility, 18, 163-204. 